\title{
ANTECIPAÇÃO DA ADUBAÇÃO DA SOJA NA CULTURA DE Eleusine coracana (L.) Gaertn., EM SISTEMA DE PLANTIO DIRETO
}

EROS ARTUR BOHAC FRANCISCO

\begin{abstract}
Dissertação apresentada à Escola Superior de Agricultura "Luiz de Queiroz", Universidade de São Paulo, para a obtenção do título de Mestre em Agronomia, Área de Concentração: Fitotecnia.
\end{abstract}

PIRACICABA

Estado de São Paulo - Brasil

Novembro - 2002 


\section{ANTECIPAÇÃO DA ADUBAÇÃO DA SOJA NA CULTURA DE Eleusine coracana (L.) Gaertn., EM SISTEMA DE PLANTIO DIRETO}

EROS ARTUR BOHAC FRANCISCO

Engenheiro Agrônomo

Orientador: Prof. Dr. GIL MIGUEL DE SOUSA CÂMARA

Dissertação apresentada à Escola Superior de Agricultura "Luiz de Queiroz", Universidade de São Paulo, para a obtenção do título de Mestre em Agronomia, Área de Concentração: Fitotecnia.

PIRACICABA

Estado de São Paulo - Brasil

Novembro - 2002 
Dados Internacionais de Catalogação na Publicação (CIP)

DIVISÃO DE BIBLIOTECA E DOCUMENTAÇÃO - ESALQ/USP

\section{Francisco, Eros Artur Bohac}

Antecipação da adubação da soja na cultura de Eleusine coracana (L.)

Gaertn., em sistema de plantio direto / Eros Artur Bohac Francisco. - -

Piracicaba, 2002.

$58 \mathrm{p.}$

Dissertação (mestrado) - - Escola Superior de Agricultura Luiz de Queiroz, 2002.

Bibliografia.

1. Adubação 2. Capim- pé- de- galinha 3. Cobertura do solo 4. Matéria seca 5. Plantio direto 6. Soja I. Título

CDD 633.34

"Permitida a cópia total ou parcial deste documento, desde que citada a fonte - $\mathrm{O}$ autor" 
Aos meus pais Eros e Wilma;

À minha irmã Íris, e meu cunhado Luís Antônio

pelo amor sempre presente no lar e pelo incentivo à vitória.

OFEREÇO

Ao meu irmão André Luís

pelo companheirismo, carinho e compreensão nos momentos difíceis.

DEDICO

A Bíblia revela o lado divino do trabalho mostrando que Deus cria e conserva, mas ao seu lado está o trabalho do homem, completando; "Dominai as aves do céu, os peixes do mar, os animais da terra" (Gn 1,28). Daí a suprema dignidade do trabalho humano.

João Mohana 


\section{AGRADECIMENTOS}

Ao Prof. Dr. Gil Miguel de Sousa Câmara, pela valiosa orientação, apoio, amizade e demonstração de respeito e caráter;

A Prof ${ }^{a}$. Dr ${ }^{\mathrm{a}}$. Sônia Maria Estéfano Piedade pela ajuda na execução e interpretação das análises estatísticas;

Ao Prof. Dr. Marcos Silveira Bernardes, pelas valiosas sugestões e amizade;

Aos colegas de pós-graduação Cláudio Roberto Segatelli, Mônica Cagnin Martins e Lília Sichmann Heiffig pela colaboração, paciência e eterna amizade;

A empresa Agronorte Pesquisa e Sementes Ltda., em especial ao colega Eng ${ }^{\text { }}$ Agr $^{\circ}$ Gerbi Luiz de Lucas, pela doação de sementes para instalação do experimento.

A Cooperativa dos Plantadores de Cana do Estado de São Paulo, em especial ao colega Eng $^{\mathbf{o}}$ Agr $^{\circ}$ Marcos Farhat, gerente do departamento técnico, pela realização das análises de solo e pela sincera amizade.

Aos funcionários da Estação Experimental Anhembi - USP/ESALQ, em especial a José Monteiro, pela colaboração na condução do experimento e amizade; 
Aos funcionários do Departamento de Produção Vegetal da USP/ESALQ - Ananias F. Sousa, César R. G. Desiderio, Wilson G. da Silva, Cláudio do E. S. Ferraz, Claudinei M. Valério, José dos Reis Lopes, Edson A. de Moraes, Edson R. Teramoto, Adilson de Jesus Teixeira, Adilson A. Dias, Antonio P. de Andrade, Daniel Luiz Theodoro, Rodrigo C. Campos, Celestino A. Ferreira, pela amizade, e contribuição na instalação do experimento;

Aos estagiários do Grupo de Pesquisas em Oleaginosas (GPO), Daniel Botelho Pedroso, Fernando Ferraz Barros, Samuel Sadao Nacamura, Melissa Pin Luchetti, Luciana Aparecida Marques, Márcia Moreira Ayres de Souza, Fábio Jordão Rocha, Marcos Antonio Mattos, Luciana Montebello de Oliveira, Renato Nogueira Rodrigues Alves Filho pela colaboração e amizade;

Aos meus amigos de república, Michel Alexandro Cambri, Francisco Nogueira Dias, Victor Martus Marcon, Rodrigo Michelini Coelho, Ulisses Calandrin, Tathyana de Abreu Batista Chaves e Lucy L. Pereira pela amizade e convivência;

Aos amigos do curso de pós-graduação que, direta e indiretamente, ajudaram com críticas e sugestões, em especial Gláucia T. Yorinori, Karina Batista, Aline M. Genu e Gilmar Ribeiro Nachtigall;

À Coordenação do curso em Fitotecnia e aos professores do curso pela colaboração e apoio;

À Coordenação de Aperfeiçoamento de Pessoal de Nível Superior (CAPES) pela concessão da bolsa de estudos. 


\section{SUMÁRIO}

Página

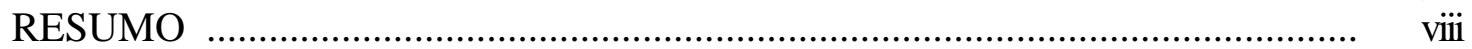

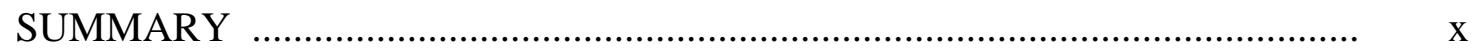

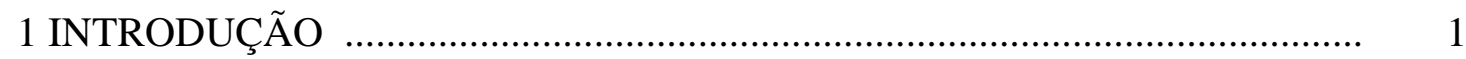

2 REVISÃO DE LITERATURA

2.1 A Cultura de Eleusine coracana (L.) Gaertn (capim-pé-de-galinha) ................ 3

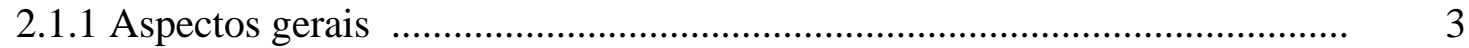

2.1.2 Adubação e produção de Eleusine coracana (L.) Gaertn ............................. 4

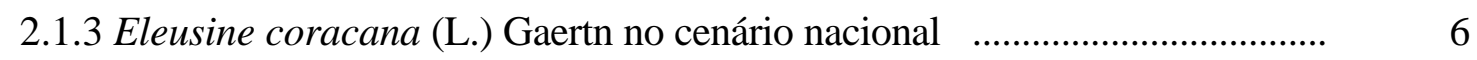

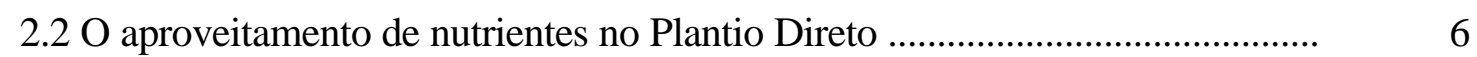

2.3 Acúmulo de matéria seca e absorção de nutrientes pela soja ............................ 9

3 MATERIAL E MÉTODOS ..................................................................... 13

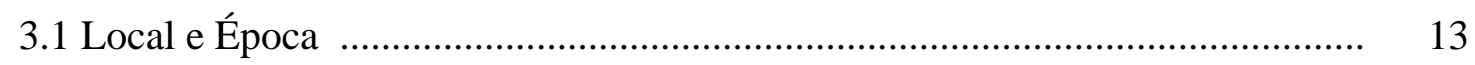

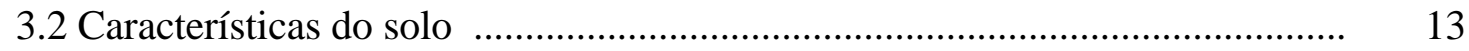

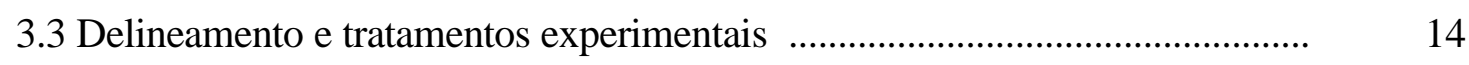

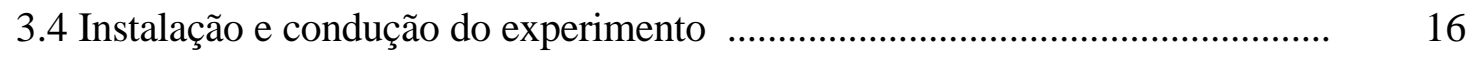

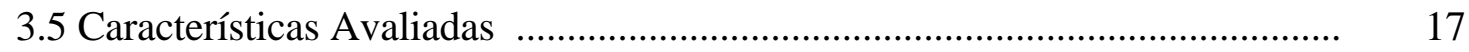

3.5.1 Produção de matéria seca, concentração e acúmulo de nutrientes pelo capim-pé-de-galinha ........................................................................... 17

3.5.2 Produção de matéria seca, concentração de nutrientes nos grãos e exportação de nutrientes pela cultura da soja ........................................... 18

3.5.3 Produtividade agrícola da cultura da soja .................................................... 17

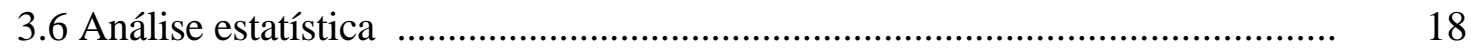


4.1 Considerações sobre a precipitação pluvial e a temperatura do ar durante o período de experimentação

4.2 Produção de matéria seca do capim-pé-de-galinha

4.3 Concentração e acúmulo de macro e micronutrientes na parte aérea do capim-pé-de-galinha

4.4 Acúmulo de matéria seca da soja

4.5 Concentração e exportação de nutrientes nos grãos de soja

4.6 Produtividade agrícola da soja

4.7 Considerações finais

5 CONCLUSÕES

ANEXOS 


\title{
ANTECIPAÇÃO DA ADUBAÇÃO DA SOJA NA CULTURA DE Eleusine coracana (L.) Gaertn., EM SISTEMA DE PLANTIO DIRETO
}

\author{
Autor: EROS ARTUR BOHAC FRANCISCO \\ Orientador: Prof. Dr. GIL MIGUEL DE SOUSA CÂMARA
}

\section{RESUMO}

O presente experimento teve por objetivo avaliar o efeito da antecipação da adubação da cultura da soja no acúmulo de matéria seca e extração de nutrientes pelo capim-pé-de-galinha (Eleusine coracana (L.) Gaertn.) e no acúmulo de matéria seca e exportação de nutrientes pela cultura da soja em sucessão, em sistema de plantio direto. $\mathrm{O}$ experimento foi conduzido em área experimental da Escola Superior de Agricultura "Luiz de Queiroz" (USP/ESALQ), no município de Piracicaba - SP, durante o ano agrícola de 2001/2002, em solo LATOSSOLO AMARELO Distrófico. O cultivar de soja utilizado foi o BRS-133. A adubação, segundo a recomendação oficial para o estado de São Paulo, consistiu da aplicação de $90 \mathrm{~kg}$ de $\mathrm{P}_{2} \mathrm{O}_{5} \mathrm{ha}^{-1}, 50 \mathrm{~kg}$ de $\mathrm{K}_{2} \mathrm{O} \mathrm{ha}^{-1}$ e de micronutrientes $(\mathrm{Co}, \mathrm{Cu}, \mathrm{Fe}, \mathrm{Mn}, \mathrm{Mo}$ e $\mathrm{Zn})$. Os tratamentos consistiram em níveis de antecipação da adubação da soja para a cultura do capim-pé-de-galinha $\left(\mathrm{T}_{1}: 0 \% ; \mathrm{T}_{2}\right.$ : $50 \%$ de P; $\mathrm{T}_{3}: 50 \%$ de $\mathrm{K} ; \mathrm{T}_{4}: 100 \%$ de $\mathrm{P} ; \mathrm{T}_{5}: 100 \%$ de $\mathrm{K} ; \mathrm{T}_{6}: 50 \%$ de $\mathrm{P}$ e K; $\mathrm{T}_{7}: 100 \%$ de $\mathrm{P}$ e $50 \%$ de $\mathrm{K} ; \mathrm{T}_{8}: 50 \%$ de $\mathrm{P}$ e $100 \%$ de $\mathrm{K} ; \mathrm{T}_{9}: 100 \%$ de $\mathrm{P}$ e $\mathrm{K} ; \mathrm{T}_{10}$ : micronutrientes; $\mathrm{T}_{11}: 100 \%$ de $\mathrm{P}$ e $\mathrm{K}+$ micronutrientes; $\mathrm{T}_{12}$ : controle), totalizando 12 tratamentos, delineados em blocos completos ao acaso com três repetições. As características 
avaliadas foram: produção de matéria seca, concentração e acúmulo dos nutrientes na parte aérea do capim-pé-de-galinha; acúmulo de matéria seca, concentração e acúmulo de nutrientes nos grãos de soja. As principais conclusões são: a) no que concerne à produtividade de matéria seca, o capim Eleusine coracana (L.) Gaertn. constitui-se em espécie recomendável à produção de palhada em sistema de produção sob plantio direto, desde que implantada em solo com média a alta fertilidade; b) considerando-se o acúmulo de nutrientes na matéria seca produzida, constata-se que o capim Eleusine coracana (L.) Gaertn. apresenta a seguinte seqüência de absorção: $\mathrm{K}>\mathrm{N}>\mathrm{Ca}>\mathrm{Mg}>\mathrm{S}$ $>\mathrm{P}>\mathrm{Mn}>\mathrm{Fe}>\mathrm{Zn}>\mathrm{Cu}$; c) a produção de matéria seca e o acúmulo dos nutrientes fósforo e cálcio pelo capim Eleusine coracana (L.) Gaertn. aumentam com a aplicação antecipada da adubação fosfatada de base recomendada para a soja; d) a antecipação da adubação de base da soja, por ocasião da instalação do capim Eleusine coracana (L.) Gaertn., não diminui o acúmulo de matéria seca e nem interfere com a exportação de nutrientes pelas plantas de soja. 


\title{
ANTICIPATION OF THE SOYBEAN FERTILIZATION ON THE Eleusine coracana (L.) Gaertn., IN A NO- TILL SYSTEM
}

\author{
Author: EROS ARTUR BOHAC FRANCISCO \\ Adviser: Prof. Dr. GIL MIGUEL DE SOUSA CÂMARA
}

\section{SUMMARY}

This research was to evaluate the effect of the anticipation of soybean fertilization on dry matter production and extraction of nutrients by finger millet (Eleusine coracana (L.) Gaertn.) and on dry matter accumulation and exportation of nutrients by soybean seed cultivated in sequence, in a no-till system. The experiment was carried out at the experimental fields of Escola Superior de Agricultura "Luiz de Queiroz" (USP/ESALQ), in Piracicaba-SP, during the growing season of 2001/2002, in an Oxisol. The cultivar used was BRS-133. The soybean fertilization, according to the official recommendation to the state of São Paulo, consisted in the application of $90 \mathrm{~kg}$ of $\mathrm{P}_{2} \mathrm{O}_{5} \mathrm{ha}^{-1}, 50 \mathrm{~kg}$ of $\mathrm{K}_{2} \mathrm{O}^{-1}$ and of micronutrients ( $\mathrm{Co}, \mathrm{Cu}, \mathrm{Fe}, \mathrm{Mn}$, Mo and $\left.\mathrm{Zn}\right)$. The treatments consisted of levels of anticipation of the soybean fertilization to the finger millet crop $\left(\mathrm{T}_{1}: 0 \% ; \mathrm{T}_{2}: 50 \%\right.$ of $\mathrm{P} ; \mathrm{T}_{3}: 50 \%$ of $\mathrm{K} ; \mathrm{T}_{4}: 100 \%$ of $\mathrm{P} ; \mathrm{T}_{5}: 100 \%$ of $\mathrm{K} ; \mathrm{T}_{6}$ : $50 \%$ of $\mathrm{P}$ and $\mathrm{K} ; \mathrm{T}_{7}: 100 \%$ of $\mathrm{P}$ and $50 \%$ of $\mathrm{K} ; \mathrm{T}_{8}: 50 \%$ of $\mathrm{P}$ and $100 \%$ of $\mathrm{K} ; \mathrm{T}_{9}: 100 \%$ of $\mathrm{P}$ and $\mathrm{K} ; \mathrm{T}_{10}$ : micronutrients; $\mathrm{T}_{1}: 100 \%$ of $\mathrm{P}$ and $\mathrm{K}+$ micronutrients; $\mathrm{T}_{12}$ : controle), totaling 12 treatments, designing a complete randomized blocks with three replications. The evaluated characteristics were: dry matter production, concentration and nutrients 
accumulation at biomass of finger millet; dry matter accumulation, nutrients concentration and accumulation in soybean seed. The main conclusions are: a) in reference to the dry matter production, Eleusine coracana (L.) Gaertn. is a recommended specie to obtain plant residues in no-till systems, since it is growing on medium to high fertility soils; b) considering the nutrients accumulation in dry matter, it is verified that Eleusine coracana (L.) Gaertn. presents the following sequence of nutrient absorption: $\mathrm{K}>\mathrm{N}>\mathrm{Ca}>\mathrm{Mg}>\mathrm{S}>\mathrm{P}>\mathrm{Mn}>\mathrm{Fe}>\mathrm{Zn}>\mathrm{Cu}$; c) the anticipation of the soybean fertilization to the Eleusine coracana (L.) Gaertn. sowing do not decrease dry matter accumulation nether interferes with the nutrients exportation by soybean seed; d) dry matter production and phosphorus and calcium accumulation by Eleusine coracana (L.) Gaertn. increase in response of phosphorus anticipation from soybean fertilization. 


\section{INTRODUÇÃO}

A cultura da soja, Glycine max (L.) Merrill, encontra-se em notável expansão nas fronteiras agrícolas do Brasil, tendo apresentado na safra 2001/2002 a produção total de 41.821.266 toneladas de grãos, em 15.845.501 hectares colhidos e o rendimento médio de $2.639 \mathrm{~kg} \mathrm{ha}^{-1}$ (FNP Consultoria, 2002). Sua importância é singular, pois, apresenta alta participação em divisas na pauta de produtos exportados, além de ser uma grande opção de cultivo para os agricultores.

O sistema de plantio direto (SPD) no Brasil também vem sendo adotado cada vez mais na região da fronteira agrícola, demonstrada na evolução que teve a área cultivada na última década. Na safra agrícola 1990/1991, a área utilizada com o SPD no Brasil era de 1,00 milhão de hectares, e já na safra 2000/2001 esse número atingiu os 17,36 milhões de hectares cultivados, sendo que o cerrado brasileiro representa $28,2 \%$ deste valor (Federação Brasileira de Plantio Direto na Palha - Febrapdp, 2002).

A introdução de novas técnicas de cultivo, dentre elas, a consolidação do sistema de plantio direto na região Centro-Oeste do país, e o desenvolvimento de novos materiais genéticos adaptados às diversas regiões brasileiras, tornou indispensável o aprimoramento de métodos de adubação, a fim de acompanhar a necessidade de constante crescimento da produtividade.

Há uma busca crescente de produção, e com isso, uma maior taxa de utilização de insumos, como os fertilizantes, cujo consumo saltou de 10.839 .371 toneladas em 1995 para 17.069.214 toneladas em 2001 (Ministério da Agricultura, 2002).

Fator determinante para obtenção de bons rendimentos na cultura da soja é a semeadura em época recomendada, pois, o desenvolvimento da planta é influenciado pela sua fotossensibilidade. A cultura da soja é uma das que mais utiliza a mecanização, 
podendo esse item representar $40 \%$ do custo total de produção (Monteiro, 2002). A aplicação de grandes quantidades de fertilizante, aliada ao tempo reduzido para semeadura, promove a queda de rendimento no processo de instalação da lavoura. Reduzir a quantidade de fertilizante na semeadura tende, logo, a melhorar o rendimento da operação.

No sistema de plantio direto são deixados na superfície do solo os restos culturais das diferentes espécies utilizadas no sistema agrícola. Essa cobertura morta tem papel importante no aspecto da conservação do solo e da reciclagem de nutrientes, e por isso, têm-se utilizado espécies com elevada produção de matéria seca no período da entressafra.

O capim-pé-de-galinha (Eleusine coracana (L.) Gaertn.), recentemente introduzido no Brasil como nova opção para a integração agricultura-pecuária e a cobertura do solo em semeadura direta, tem sido utilizado em sistemas agrícolas, antecedendo a cultura da soja, nos estados da região Centro-Oeste do Brasil. Contudo, existem poucos estudos a respeito desta planta em condições brasileiras, e a sua utilização é baseada na adaptação de técnicas de cultivo de outras espécies gramíneas.

Assim, a execução deste trabalho teve por finalidade, estudar os efeitos da adubação antecipada da cultura da soja sobre a produção de biomassa e extração de nutrientes do capim-pé-de-galinha e a produção de matéria seca e a exportação de nutrientes pela cultura da soja quando cultivada em sucessão.

As hipóteses foram as seguintes:

- a produção de matéria seca e acúmulo de nutrientes pelo capim-pé-de-galinha devem aumentar com a aplicação de P e K.

- o acúmulo de matéria seca ao longo do ciclo da soja não deve diminuir com a antecipação da adubação de P e K. 


\section{REVISÃO DE LITERATURA}

\subsection{A Cultura de Eleusine coracana (L.) Gaertn. (capim-pé-de-galinha)}

\subsubsection{Aspectos gerais}

A espécie Eleusine coracana (L.) Gaertn. teve sua origem em Uganda, leste da África, e foi introduzida na Índia há 3.000 anos. Essa espécie é conhecida em vários locais do mundo como Raji (Índia), Wimbi (Swakili), Bulo (Uganda) e Telebun (Sudão), e, é uma importante cultura da África e Ásia, particularmente no sul da Índia, (FAO, 1995). No Brasil, vem sendo denominada capim-pé-de-galinha, porém, sem nenhuma relação com a planta daninha Eleusine indica (L.).

A principal forma de utilização do grão é na alimentação humana. Convencionalmente, é utilizado nas indústrias indianas de bebidas e cervejarias, embora seja, ocasionalmente, utilizado na alimentação de mulheres em lactação. Em outras partes, sua farinha é utilizada para confecção de pães e bolos, Oduori (1994).

Em Zâmbia, segundo Agrawal (1994), é utilizado para alimentar pássaros durante os meses de dezembro e janeiro a fim de prevenir danos às culturas em emergência. Segundo Mushonga (1994), no Zimbabwe o grão é usado na alimentação de aves de corte e suínos, enquanto a forragem é usada na alimentação de bovinos, ovinos e caprinos. Na Etiópia, segundo Mulatu \& Kebede (1994), as regiões produtoras são dependentes da cultura, por se desenvolver relativamente bem em anos secos e garantir alimento em tempo de escassez. 
De acordo com Purseglove ${ }^{1}$, citado em Mulatu \& Kebede (1994), o grande mérito do Eleusine coracana é que pode ser armazenado por períodos de até 10 anos, ou mais, sem sofrer danos de deterioração.

Atualmente, no Brasil, trata-se de uma espécie gramínea introduzida como planta forrageira nas regiões da fronteira agrícola brasileira (baixas latitudes) e que, recentemente, vem sendo utilizada como cobertura morta na semeadura direta da soja e no sistema de integração lavoura-pecuária, (de Lucas) ${ }^{2}$. Apesar disso, não se encontra na bibliografia nacional, trabalhos científicos relacionados ao estudo agrobotânico desta espécie e nem ao seu uso em rotação de culturas.

\subsubsection{Adubação e produção de Eleusine coracana (L.) Gaertn.}

Devido sua utilização para alimentação humana nos países já mencionados, o capim-pé-de-galinha é estudado como cultura econômica e as técnicas de cultivo são aprimoradas para obtenção de melhores rendimentos, principalmente, através da pesquisa realizada por universidades indianas.

O nitrogênio ocupa posição de destaque entre os elementos essenciais ao desenvolvimento das plantas, sendo grande sua necessidade pelos vegetais, e um dos nutrientes mais limitantes à produtividade da maioria das culturas. $\mathrm{O}$ estudo desenvolvido por Rao et al. (1989) demonstrou a resposta significativa da adubação nitrogenada sobre o rendimento de grãos, a altura de plantas e o número de perfilhos por planta, bem como sobre a produção de biomassa do capim-pé-de-galinha. Quanto à época de aplicação do nitrogênio, Rao et al. (1991) observaram haver grande influência. Em um experimento conduzido por dois anos, os autores observaram que, quando a dose da adubação nitrogenada era dividida em três subdoses, ao invés de duas, obtinha-se substancial aumento no rendimento de grãos, provavelmente causado pelo incremento do peso de espigas e do peso de mil grãos. Esta resposta, segundo os autores, deveu-se ao fato de a terceira subdose coincidir com a época de formação de espigas,

\footnotetext{
${ }^{1}$ PURSEGLOVE, J.W. Tropical crops monocotyledons. London: Longman, 1972

2 de LUCAS, G.L. Comunicação pessoal, 2001
} 
demonstrando assim, a influência não só da quantidade da adubação nitrogenada, como da sua época de aplicação.

Para avaliar o efeito da aplicação de fertilizantes no rendimento da biomassa produzida, Subba Rao \& Prabhu (1996) experimentaram três doses de adubação NPK: 0, 50 e $100 \mathrm{~kg} \mathrm{ha}^{-1}$ de $\mathrm{N}$ e 0,25 e $50 \mathrm{~kg} \mathrm{ha}^{-1}$ de $\mathrm{P}_{2} \mathrm{O}_{5}$ e $\mathrm{K}_{2} \mathrm{O}$; em três cultivares, concluindo que há diferença na qualidade da matéria seca entre as variedades e que a maior dose de NPK incrementou o total de biomassa seca produzida em relação a testemunha $(12$ e $8 \mathrm{t}$ $\mathrm{ha}^{-1}$, respectivamente).

O fósforo é um nutriente importante na nutrição mineral, estando relacionado com a produção de energia e o crescimento de plantas. $\mathrm{O}$ estudo desenvolvido por Pilane et al. (1997) constatou que doses crescentes de nitrogênio $\left(25,50,75\right.$ e $\left.100 \mathrm{~kg} \mathrm{ha}^{-1}\right)$ e fósforo $\left(12,5 ; 50 ; 37,5\right.$ e $\left.50 \mathrm{~kg} \mathrm{ha}^{-1}\right)$ aplicadas na cultura do capim-pé-de-galinha, em dois anos de experimentação, incrementaram os caracteres produtivos como: peso de panícula, peso de grãos por panícula e o rendimento. Os autores comentam ter havido resposta no primeiro ano para doses até 50 e $25 \mathrm{~kg} \mathrm{ha}^{-1}$ de $\mathrm{N}$ e $\mathrm{P}$, respectivamente, devido a inadequada quantidade de chuvas. Enquanto no segundo ano, houve resposta para doses de $100 \mathrm{~kg} \mathrm{ha}^{-1}$ de $\mathrm{N}$ e $50 \mathrm{~kg} \mathrm{ha}^{-1}$ de $\mathrm{P}$.

Para os elementos potássio, cálcio e magnésio, Mathan (1995) estudou a absorção de magnésio em relação aos demais íons presentes no solo, especialmente o $\mathrm{Ca}^{2+}$ e o $\mathrm{K}^{+}$, conduzindo um experimento para avaliar o efeito direto dos íons $\mathrm{Mg}^{2+}, \mathrm{Ca}^{2+}$ e $\mathrm{K}^{+}$no rendimento e na absorção de magnésio pelo Eleusine coracana, onde foram utilizadas duas doses de potássio (0 e $\left.100 \mathrm{~kg} \mathrm{ha}^{-1}\right)$, quatro doses de magnésio $(0,50,100$ e $150 \mathrm{~kg} \mathrm{ha}^{-1}$ ) e as condições com e sem calagem. $\mathrm{O}$ autor verificou que o rendimento de grãos e matéria seca aumentou significativamente com a aplicação de até $50 \mathrm{~kg} \mathrm{ha}^{-1}$ de $\mathrm{Mg}^{2+}$, e que acima deste valor houve redução. A aplicação de doses crescentes de $\mathrm{Mg}^{2+}$, associadas a nenhuma aplicação de $\mathrm{K}^{+}$, resultou em maior rendimento de grãos, havendo redução neste parâmetro quando acrescentada a dose de $100 \mathrm{~kg} \mathrm{ha}^{-1}$ de $\mathrm{K}_{2} \mathrm{O}$ às doses crescentes de $\mathrm{Mg}^{+}$. Com a adição de calcário junto à dose zero de $\mathrm{Mg}^{2+}$, houve acréscimo significativo na produção de matéria seca total da planta, enquanto essa 
resposta tornou-se ausente quando doses elevadas de magnésio (100 e $150 \mathrm{~kg} \mathrm{ha}^{-1}$ ) foram aplicadas.

\subsubsection{Eleusine coracana (L.) Gaertn no cenário nacional}

Com o desenvolvimento do plantio direto no Brasil, várias espécies têm sido testadas com a finalidade de fornecer biomassa para o sistema, reciclar nutrientes e promover a estruturação do solo. Para tanto, buscam-se espécies que resistam a períodos de estresse hídrico e sejam de fácil manejo.

Com esse intuito, foi introduzida no Brasil a espécie Eleusine coracana (L.) Gaertn, no ano de 1995, no estado de Mato Grosso. As características inerentes à espécie vêm aguçando o interesse dos agricultores em utilizá-la como formadora de palhada. No entanto, a pesquisa referente a este material em condições brasileiras ainda é bastante escassa, sendo desenvolvida de modo primário em algumas regiões do país. De acordo com Salton ${ }^{3}$, a espécie foi semeada no ano agrícola de 2000/2001 nas unidades da Embrapa em Dourados-MS (Centro de Pesquisa Agropecuária do Oeste) e Brasília-DF (Centro de Pesquisa Agropecuária do Cerrado).

\subsection{O aproveitamento de nutrientes no Plantio Direto}

O plantio direto é um processo de semeadura em solo não revolvido e devidamente protegido por resíduos de culturas anteriores, no qual as sementes são colocadas em sulcos ou covas, com largura e profundidade suficientes para adequada cobertura e contato das mesmas com a terra (Muzilli, 1981).

A quantidade e a qualidade da palha sobre a superfície do solo dependem do sistema de rotação adotado e, em grande parte, do tipo de planta de cobertura e do manejo que lhe é dado. A maior produção de fitomassa indica maior oferta de palha

${ }^{3}$ SALTON, J.C. Comunicação pessoal, 2001. 
sobre o solo, podendo, ainda, dar uma idéia sobre a reciclagem de nutrientes desde que se conheça o padrão de extração de nutrientes da espécie (Alvarenga et al., 2001).

Os sistemas de manejo sem revolvimento do solo e com elevado aporte de resíduos vegetais, como o plantio direto, favorecem o acúmulo de matéria orgânica no solo e induzem a uma diminuição no seu grau de humificação (Bayer \& Mielniczuc, 1997). Esse aporte constante de resíduos orgânicos ao solo favorece a ciclagem dos nutrientes, e quando o material vegetal é de baixa taxa de decomposição (elevada relação $\mathrm{C} / \mathrm{N}$ ), ocorre o favorecimento do processo de humificação, criando uma reserva de nutrientes no solo. Já, quando o aporte for de material vegetal de rápida decomposição (baixa relação $\mathrm{C} / \mathrm{N}$ ) haverá uma rápida mineralização dos nutrientes, (Mendonça \& Oliveira, 2000).

Em relação à ciclagem biológica, o plantio direto tende a maximizar a conservação de nutrientes no agroecossistema, bem como reduzir suas perdas, quando há a manutenção da palhada sem revolvimento do solo (Wisniewski \& Holtz, 1997). Vários estudos têm demonstrado as alterações nos atributos químicos do solo em função do sistema de cultivo. Em solos tropicais e subtropicais, a capacidade de troca de cátions (CTC) da matéria orgânica do solo (MOS) pode representar um grande percentual da CTC total do solo (Bayer \& Mielniczuk, 1999), visto que as substâncias húmicas apresentam valores (400 a $1400 \mathrm{cmol}_{\mathrm{c}} \mathrm{kg}^{-1}$ ) superiores aos de alguns minerais de argila como a caulinita (3-5 $\left.\mathrm{cmol}_{\mathrm{c}} \mathrm{kg}^{-1}\right)$, a ilita $\left(30-40 \mathrm{cmol}_{\mathrm{c}} \mathrm{kg}^{-1}\right)$ e a montmorilonita (80-150 $\mathrm{cmol}_{\mathrm{c}} \mathrm{kg}^{-1}$ ) (Canellas et al., 1999). A perda de solo por erosão também implica na perda de nutrientes da camada arável e o estudo de Noleto \& Goedert (1999) mostrou que o sistema de plantio direto proporcionou redução de perda de solo de $78 \%$ quando comparado com o plantio convencional.

Do ponto de vista químico, Santos et al. (2001) comentam que, em geral, os solos cultivados sob plantio direto apresentam maior concentração de $\mathrm{Ca}+\mathrm{Mg}$ trocáveis, de matéria orgânica, de $\mathrm{P}$ extraível e $\mathrm{K}$ trocável na camada superficial do perfil $(0-5 \mathrm{~cm})$. Esse acúmulo decorre da aplicação freqüente de fertilizantes em pequenas profundidades e é devido à contribuição biológica de $\mathrm{N}$ das leguminosas, aliada à deposição de resíduos de culturas sobre a superfície, os quais aí permanecem pelo não revolvimento do solo. 
O trabalho de Muzilli (1983), comparando o cultivo convencional com o plantio direto, demonstrou que houve incremento, nos primeiros $10 \mathrm{~cm}$ de profundidade, do teor de fósforo disponível no solo, após 5 anos de cultivo. $\mathrm{O}$ autor explica que o acúmulo de fósforo nas camadas superficiais sob plantio direto se deve à imobilidade e baixa solubilidade de seus compostos, sobretudo em solos de natureza ácida, e que essa maior disponibilidade de fósforo, através do tempo, pode reduzir os gastos com fertilizantes, uma vez que superado o nível critico no solo.

Devido à reciclagem de nutrientes realizada pela mineralização da biomassa das culturas de cobertura, que antecedem as culturas de valor comercial em um sistema rotacionado com semeadura direta, a recomendação de adubação deve ser em quantidade menor quando comparada ao sistema de semeadura com preparo convencional do solo (Borkert et al., 1999). Esses autores estudaram a quantidade de nutrientes presentes na matéria seca (MS) de cinco espécies utilizadas como culturas de cobertura e observaram que a aveia preta e a ervilhaca se caracterizam como recicladoras de grande quantidade de potássio (23,3 e 22,9 $\mathrm{kg}$ de $\mathrm{K}$ por tonelada de MS, respectivamente). A ervilhaca, a mucuna preta, o tremoço e o guandú reciclam grande quantidade de nitrogênio (46,2; 34,4; 33,8 e 30,1 kg de $\mathrm{N}$ por tonelada de MS, respectivamente). Todas as espécies também reciclam quantidades consideráveis de cálcio, magnésio e micronutrientes, porém baixas quantidades de fósforo (média de $2,55 \mathrm{~kg}$ de $\mathrm{P}$ por tonelada de $\mathrm{MS}$ ).

A estratégia proposta por Muzilli (2000) consiste em manter a fertilidade do solo em níveis adequados e cultivar plantas de cobertura capazes de aproveitar o efeito residual das adubações realizadas nas culturas comerciais, contribuindo, assim, para promover efeitos de ciclagem ao longo do perfil cultural do solo.

A presença de resíduos de culturas na superfície do solo representa uma fonte de restituição de nutrientes ao solo, podendo ser mensurada através dos estudos de extração pelas culturas de rotação. Marques et al. (2002) determinaram a restituição de elementos ao solo pelas culturas do milheto e da aveia antecedendo as culturas de soja e milho. A quantidade de nutrientes presentes nos restos culturais de milheto foi da ordem de: 122, 15, 124, 26, 17 e $8 \mathrm{~kg} \mathrm{ha}^{-1}$ de N, P, K, Ca, Mg e S, respectivamente; enquanto nos restos culturais da aveia: $61,8,60,12,5$ e $6 \mathrm{~kg} \mathrm{ha}^{-1}$ de $\mathrm{N}, \mathrm{P}, \mathrm{K}, \mathrm{Ca}, \mathrm{Mg}$ e S, respectivamente. 
Wisniewski \& Holtz (1997), estudaram a decomposição da palhada e a liberação de fósforo numa rotação de aveia-preta e soja em semeadura direta, contendo restos culturais de milho, provenientes de sua colheita, antes do plantio da aveia. Os autores constataram maior taxa de mineralização da palha de aveia (85\% em 179 dias), em comparação com a taxa da palha do milho (77\% em 149 dias). Contudo, a velocidade de mineralização da aveia-preta é menor do que a velocidade de mineralização do milho, o que para soja seria mais indicado, pois estaria disponibilizando o fósforo por tempo mais prolongado.

\subsection{Acúmulo de matéria seca e absorção de nutrientes pela soja}

A produção agrícola por unidade de área está relacionada com parâmetros fisiológicos importantes como: taxa de crescimento da cultura, índice de área foliar (IAF), taxa de assimilação líquida de carbono, índice de colheita e a produção de matéria seca (Fageria et al., 1997). O acúmulo de matéria seca de uma planta é o resultado da troca de $\mathrm{CO}_{2}$ entre ela e a atmosfera, e é função de fatores ambientais (temperatura, radiação solar e umidade), do material genético cultivado e das práticas de manejo adotadas (Fageria et al., 1997).

Dentro do ciclo de vida das plantas anuais, três fases de crescimento podem ser distinguidas: uma fase inicial exponencial, uma fase de pleno crescimento e a fase de amadurecimento e senescência (Goudriaan \& Laar, 1994). O ciclo da soja, de acordo com Mascarenhas (1973), é dividido em três períodos distintos, que correspondem às alterações no desenvolvimento fisiológico da planta. Aplicando-se a Fenologia da Soja proposta por Fehr \& Caviness (1977) ao trabalho de Mascarenhas (1973), tem-se que o primeiro período é a fase da emergência $\left(V_{E}\right)$ ao início do florescimento $\left(R_{1}\right)$; o segundo é a fase do final do pleno florescimento $\left(\mathrm{R}_{2}\right)$ ao início da formação de vagens $\left(\mathrm{R}_{3}\right)$; o terceiro período é a fase do crescimento das vagens $\left(\mathrm{R}_{4}\right)$ ao início da queda das folhas $\left(\mathrm{R}_{7}\right)$.

Segundo Cordeiro et al. (1980), a produção de matéria seca, em presença de fertilizantes aplicados ao solo, fornece subsídios como indicadores do crescimento das 
plantas, visto que a nutrição equilibrada favorece o metabolismo celular, e conseqüentemente, a integridade dos tecidos. Rosolem \& Marcello (1998), estudando a nutrição mineral da soja em função da calagem e da adubação fosfatada, verificaram que a calagem não teve efeito significativo na produção de matéria seca da soja, e que houve resposta ao fósforo, em termos de matéria seca total da planta, sendo a resposta mais acentuada, quanto maior a saturação por bases e, portanto, maior o teor de cálcio no solo. Freire \& Sarruge (1979) também obtiveram aumento da produção de matéria seca das raízes e da parte aérea em resposta à adubação fosfatada.

O estudo do acúmulo de matéria seca e da absorção de nutrientes pela cultura da soja é essencial para se avaliar o efeito da mineralização de restos vegetais em decomposição existentes no sistema de semeadura direta. Estimativas das quantidades de nutrientes extraídas pela cultura da soja e a remoção pelos grãos foram obtidas por Bataglia \& Mascarenhas (1977). De acordo com os autores, o N e o K são os nutrientes requeridos em maiores quantidades pela soja, seguidos de $\mathrm{Ca}, \mathrm{Mg}, \mathrm{P}$ e S. Entretanto, foi observado que cerca de 75 a $85 \%$ do $\mathrm{Ca}$ e 50 a $78 \%$ do $\mathrm{Mg}$ acumulados retornam ao solo nos restos da cultura, de modo que a quantidade de nutrientes exportada pelos grãos segue a ordem: $\mathrm{N}>\mathrm{K}>\mathrm{P}>\mathrm{Ca}>\mathrm{Mg}=\mathrm{S}$.

Caires \& Fonseca (2000), estudando o efeito da calagem em superfície no plantio direto, detectaram que a extração de nutrientes pela planta de soja ocorreu na mesma seqüência obtida por Bataglia \& Mascarenhas (1977): $\mathrm{N}>\mathrm{K}>\mathrm{Ca}>\mathrm{P}>\mathrm{Mg}>\mathrm{S}$. Os autores comentam não ter havido influência significativa da calagem superficial na absorção de $\mathrm{N}, \mathrm{K}, \mathrm{Ca}$ e $\mathrm{S}$, enquanto, na absorção do $\mathrm{P}$ e do $\mathrm{Mg}$ houve. A produção de grãos e de matéria seca das plantas também não foi influenciada significativamente.

O trabalho de Bataglia et al. (1976) mostrou que o acúmulo máximo de matéria seca pela planta ocorreu na fase inicial da formação de vagens, coincidindo com o ponto de maior desenvolvimento da parte vegetativa (folhas, caules e raízes). Após essa fase, ocorreu uma elevação da matéria seca na parte reprodutiva (vagens), principalmente pelos grãos. O autor observou que a velocidade de absorção do potássio é mais rápida que o acúmulo de matéria seca, e já o fósforo é absorvido em velocidade relativamente menor que o acúmulo de matéria seca, sendo que há, para os dois nutrientes, redução 
após o ponto de máxima absorção, concluindo que a disponibilidade de potássio deve ser maior no início do desenvolvimento da planta até o ponto de maior acúmulo de matéria seca, enquanto que o fósforo necessita estar disponível em todo o ciclo de desenvolvimento da cultura.

Hanway \& Weber (1971a), verificaram que aplicações moderadas de P e K tinham efeitos pequenos sobre a massa da matéria seca e sobre o rendimento, mas, elevadas aplicações de $\mathrm{KCl}$ reduziram significativamente esses dois parâmetros.

No que se refere à absorção, Krantz et al. ${ }^{4}$, citados por Vernetti (1983), mostraram que de 70 a $100 \%$ do fósforo das plantas, nos primeiros estágios de crescimento, podem ser provenientes do fertilizante, sendo o nutriente absorvido continuamente até o fim do seu ciclo, embora a maior parte seja de dois a três meses após a aplicação. O fósforo aplicado nas linhas ficou disponível até a época da colheita.

Kanthack (1995), em seu trabalho, concluiu não ter havido diferença no rendimento da soja em função de doses crescentes de $\mathrm{K}_{2} \mathrm{O}$ aplicadas $(30,60$, 90 e $120 \mathrm{~kg}$ $\left.\mathrm{ha}^{-1}\right)$. No entanto, houve influência da dose aplicada no índice de área foliar, na taxa de assimilação líquida, na taxa de crescimento cultural e no acúmulo de massa de matéria seca da parte aérea, mostrando o papel fundamental desse nutriente nos parâmetros de crescimento, desenvolvimento e nutrição da cultura.

Esteves (2000) trabalhou com soja em sucessão às culturas de inverno (aveia preta e milheto) submetendo o sistema à antecipação da adubação $\mathrm{P}$ e $\mathrm{K}$, visando verificar o efeito da disponibilidade residual destes nutrientes nas características qualitativas e produtivas da soja; concluiu que, nas condições do experimento, a cultura da aveia preta acumulou teores de $\mathrm{P}$ e $\mathrm{K}$ maiores que a cultura do milheto; a degradação da palhada da aveia preta foi mais rápida que a do milheto; após o dessecamento, o $\mathrm{K}$ acumulado nos adubos verdes é liberado em mais de $90 \%$ no solo em um período de 60 dias; o cultivo de espécies durante o inverno, recebendo adubação fosfatada, aumenta a disponibilidade de $\mathrm{P}$ para a cultura seguinte; o teor de $\mathrm{P}$ e $\mathrm{K}$ nas plantas de soja e a produção de soja foram maiores quando não se antecipou a adubação do sistema.

\footnotetext{
${ }^{4}$ KRANTS, B. A.; NELSON, W. L.; WELCH, C.D.; HALL, N. S. A comparison of phosphorus utilization by crops. Soil Science, v.68, p.171-175, 1949.
} 
Foloni et al. (2000) também estudaram a antecipação da adubação potássica da soja em sistema de rotação com o milheto, interagindo doses de 0, 30, 60 e $90 \mathrm{~kg} \mathrm{~K}_{2} \mathrm{O}$ $\mathrm{ha}^{-1}$. De acordo com os autores, a antecipação da adubação potássica na semeadura do milheto, cultivado na primavera, não comprometeu o rendimento de grãos da soja, chegando a incrementar em alguns casos, como quando se aplicou de 60 a $90 \mathrm{~kg} \mathrm{ha}^{-1} \mathrm{de}$ $\mathrm{K}_{2} \mathrm{O}$ quer no milheto, quer na soja ou parcelado. 


\section{MATERIAL E MÉTODOS}

\subsection{Local e Época}

A pesquisa foi realizada em condições de campo em área experimental pertencente a Escola Superior de Agricultura "Luiz de Queiroz", denominada Estação Experimental Anhembi, localizada à margem direita do Rio Tietê, dentro da bacia de acúmulo da represa de Barra Bonita-SP, e pertencente ao município de Piracicaba-SP, entre as coordenadas de $22^{\circ} 45^{\prime}$ e $22^{\circ} 50^{\prime}$ de Latitude Sul, $48^{\circ} 00^{\prime}$ e $45^{\circ} 05^{\prime}$ de Longitude Oeste e $530 \mathrm{~m}$ de altitude média. A área tem histórico de vinte anos de pastagem seguidos de dois anos com cultivo de milho, tendo sido efetuada a correção da acidez do solo e a adubação para a cultura do milho.

Foi conduzida durante o ano agrícola de 2001/2002, iniciando-se com a semeadura do capim-pé-de-galinha (Eleusine coracana (L.) Gaertn.) em 06 de setembro, para obtenção de cobertura morta, e a semeadura da soja em 06 de dezembro. Finalizando-se com a colheita das parcelas em 12 de abril de 2002.

\subsection{Características do solo}

O solo da área experimental é classificado como LATOSSOLO AMARELO Distrófico, contendo $200 \mathrm{~g} \mathrm{~kg}^{-1}$ de argila, $80 \mathrm{~g} \mathrm{~kg}^{-1}$ de silte e $720 \mathrm{~g} \mathrm{~kg}^{-1}$ de areia. Suas características químicas são apresentadas nas Tabelas 1 e 2 . 
Tabela 1. Análise química do solo da área experimental, nas profundidades de 00 a 20, 20 a 40 e 40 a $60 \mathrm{~cm}$

\begin{tabular}{|c|c|c|c|c|c|c|c|c|c|c|c|c|c|}
\hline \multirow{2}{*}{$\begin{array}{l}\text { Prof. }{ }^{1} \\
\mathrm{~cm}\end{array}$} & \multirow{2}{*}{$\begin{array}{c}\mathrm{pH} \\
\mathrm{CaCl}_{2}\end{array}$} & \multirow{2}{*}{$\begin{array}{l}\text { M.O. } \\
\mathrm{g} \mathrm{dm}^{-3}\end{array}$} & $\mathrm{P}$ & S & \multirow{2}{*}{\multicolumn{7}{|c|}{$\mathrm{mmol}_{c} \mathrm{dm}^{-3}$}} & V & $\mathrm{m}$ \\
\hline & & & & $\mathrm{Im}^{-3}$ & & & & & & & & \multicolumn{2}{|c|}{$\%$} \\
\hline $00-20$ & 6,4 & 31 & 6 & 19 & 1,9 & 22 & 15 & 1 & 22 & 38,9 & 60,9 & 64 & 3 \\
\hline $20-40$ & 3,9 & 21 & 4 & 32 & 1,2 & 9 & 6 & 12 & 47 & 16,2 & 63,2 & 26 & 43 \\
\hline $40-60$ & 4,5 & 16 & 3 & 35 & 0,9 & 6 & 3 & 16 & 42 & 9,9 & 51,9 & 19 & 62 \\
\hline
\end{tabular}

${ }^{\mathrm{T}}$ Prof. = profundidade de amostragem.

Tabela 2. Teores de micronutrientes do solo da área experimental, nas profundidades de 00 a 20,20 a 40 e 40 a $60 \mathrm{~cm}$

\begin{tabular}{cccccc}
\hline Prof. $^{1}$ & $\mathrm{~B}$ & $\mathrm{Cu}$ & $\mathrm{Fe}$ & $\mathrm{Mn}$ & $\mathrm{Zn}$ \\
\hline $\mathrm{cm}$ & & & $\mathrm{mg} \mathrm{dm}^{-3}$ & & \\
$00-20$ & - & 0,8 & 88 & 4,4 & 0,9 \\
$20-40$ & - & 2,2 & 47 & 0,4 & 2,8 \\
$40-60$ & - & 1,1 & 35 & 0,6 & 1,1 \\
\hline
\end{tabular}

${ }^{\mathrm{T}}$ Prof. = profundidade de amostragem.

\subsection{Delineamento e tratamentos experimentais}

O delineamento experimental adotado foi o de blocos ao acaso, constituídos por doze tratamentos (níveis de antecipação da adubação) e três repetições, sendo o fator experimental o próprio tratamento.

O experimento foi instalado de modo a antecipar a adubação de base da cultura da soja colocando-a, parcial e totalmente, na semeadura do capim-pé-de-galinha, de acordo com o esquema apresentado na Tabela 3. 
Tabela 3. Tratamentos experimentais aplicados ao capim-pé-de-galinha e a soja

\begin{tabular}{|c|c|c|}
\hline & Capim-pé-de-galinha & Soja \\
\hline $\mathrm{T} 1$ & Testemunha 1 (sem adubação) & Adubação Total Recomendada (ATR) \\
\hline $\mathrm{T} 2$ & $50 \%$ de $\mathrm{P}_{2} \mathrm{O}_{5}$ da ATR & ATR (-) $50 \%$ de $\mathrm{P}_{2} \mathrm{O}_{5}$ \\
\hline $\mathrm{T} 3$ & $50 \%$ de $\mathrm{K}_{2} \mathrm{O}$ da ATR & ATR (-) $50 \%$ de $\mathrm{K}_{2} \mathrm{O}$ \\
\hline $\mathrm{T} 4$ & $100 \%$ de $\mathrm{P}_{2} \mathrm{O}_{5}$ da ATR & ATR (-) $100 \%$ de $\mathrm{P}_{2} \mathrm{O}_{5}$ \\
\hline $\mathrm{T} 5$ & $100 \%$ de $\mathrm{K}_{2} \mathrm{O}$ da ATR & ATR (-) $100 \%$ de $\mathrm{K}_{2} \mathrm{O}$ \\
\hline \multirow{2}{*}{ T6 } & $50 \%$ de $\mathrm{P}_{2} \mathrm{O}_{5}$ da ATR & ATR (-) $50 \%$ de $\mathrm{P}_{2} \mathrm{O}_{5}$ \\
\hline & $50 \%$ de $\mathrm{K}_{2} \mathrm{O}$ da ATR & ATR (-) $50 \%$ de $\mathrm{K}_{2} \mathrm{O}$ \\
\hline \multirow{2}{*}{$\mathrm{T} 7$} & $100 \%$ de $\mathrm{P}_{2} \mathrm{O}_{5}$ da ATR & ATR (-) $100 \%$ de $\mathrm{P}_{2} \mathrm{O}_{5}$ \\
\hline & $50 \%$ de $\mathrm{K}_{2} \mathrm{O}$ da ATR & ATR (-) $50 \%$ de $\mathrm{K}_{2} \mathrm{O}$ \\
\hline \multirow{2}{*}{$\mathrm{T} 8$} & $50 \%$ de $\mathrm{P}_{2} \mathrm{O}_{5}$ da ATR & ATR (-) $50 \%$ de $\mathrm{P}_{2} \mathrm{O}_{5}$ \\
\hline & $100 \%$ de $\mathrm{K}_{2} \mathrm{O}$ da ATR & ATR (-) $100 \%$ de $\mathrm{K}_{2} \mathrm{O}$ \\
\hline \multirow{2}{*}{$\mathrm{T} 9$} & $100 \%$ de $\mathrm{P}_{2} \mathrm{O}_{5}$ da ATR & ATR (-) $100 \%$ de $\mathrm{P}_{2} \mathrm{O}_{5}$ \\
\hline & $100 \%$ de $\mathrm{K}_{2} \mathrm{O}$ da ATR & ATR (-) $100 \%$ de $\mathrm{K}_{2} \mathrm{O}$ \\
\hline \multirow{2}{*}{$\mathrm{T} 10$} & ATR (-) $100 \%$ de $\mathrm{P}_{2} \mathrm{O}_{5}$ & $100 \%$ de $\mathrm{P}_{2} \mathrm{O}_{5}$ da ATR \\
\hline & $\operatorname{ATR}(-) 100 \%$ de $\mathrm{K}_{2} \mathrm{O}$ & $100 \%$ de $\mathrm{K}_{2} \mathrm{O}$ da ATR \\
\hline $\mathrm{T} 11$ & ATR & Testemunha 1 (sem adubação) \\
\hline $\mathrm{T} 12$ & Testemunha 2 (sem adubação) & Testemunha 2 (sem adubação) \\
\hline
\end{tabular}

A ATR (Adubação Total Recomendada), refere-se à adubação recomendada para a cultura da soja em sistemas de alta tecnologia, segundo a recomendação de adubação para a cultura da soja para o estado de São Paulo, contida no Boletim Técnico $\mathrm{n}^{\mathbf{0}} 100$ do Instituto Agronômico de Campinas-SP, levando-se em consideração a fertilidade do solo e a produtividade esperada. A recomendação adotada consistiu da aplicação de 90 $\mathrm{kg} \mathrm{ha}^{-1}$ de $\mathrm{P}_{2} \mathrm{O}_{5}$, na forma de superfosfato triplo (45\% de $\mathrm{P}_{2} \mathrm{O}_{5}$ ), $50 \mathrm{~kg} \mathrm{ha}^{-1}$ de $\mathrm{K}_{2} \mathrm{O}$ na forma de cloreto de potássio $\left(60 \%\right.$ de $\left.\mathrm{K}_{2} \mathrm{O}\right)$ e da aplicação via foliar dos micronutrientes 
Co e Mo, na dose de $150 \mathrm{~mL} \mathrm{~h}^{-1}$ do produto comercial (Co: 3,825 $\mathrm{g} \mathrm{ha}^{-1}$; Mo: 38,25 $\mathrm{g}$ $\mathrm{ha}^{-1}$ ) e $\mathrm{B}, \mathrm{Cu}, \mathrm{Mn}$, e $\mathrm{Zn}$, na dose de $2 \mathrm{~L} \mathrm{ha}^{-1}$ do produto comercial (B: 12,6 $\mathrm{g} \mathrm{ha}^{-1}$; $\mathrm{Cu}$ :

12,6 $\mathrm{g} \mathrm{ha}^{-1}$; Mn: 75,6 $\mathrm{g} \mathrm{ha}^{-1}$; Zn: $126 \mathrm{~g} \mathrm{ha}^{-1}$ ). Todos os tratamentos, em sua totalidade, receberam a ATR completa, com exceção do tratamento 12.

A parcela experimental foi dimensionada para conter dezoito linhas de soja com $12 \mathrm{~m}$ de comprimento, espaçadas de $0,50 \mathrm{~m}$, totalizando uma área de $108 \mathrm{~m}^{2}$.

\subsection{Instalação e condução do experimento}

Antes da implantação do experimento, realizou-se o diagnóstico preliminar da área, com relação às propriedades químicas e granulométricas do solo. Amostras das camadas de 0 a 5,5 a 10, 10 a 20 e 20 a $40 \mathrm{~cm}$ foram retiradas com trado tipo sonda e, com base nos resultados da análise, detectou-se a ausência da necessidade de calagem para correção da acidez do solo. Procedeu-se, então, o revolvimento do solo com grade aradora. Para tentar minimizar a possível interferência da elevada saturação por alumínio na profundidade de 20 a $40 \mathrm{~cm}$, utilizou-se o gesso agrícola na dose de $500 \mathrm{~kg} \mathrm{ha}^{-1}$, incorporando-o ao solo com o uso de grade niveladora.

Antes da semeadura do capim-pé-de-galinha, promoveu-se a adubação, à lanço, das parcelas experimentais cujos tratamentos indicavam a antecipação. $O$ cultivar utilizado para a semeadura do capim-pé-de-galinha foi o "ANSB Pé-de-galinha 5352" pertencente à espécie Eleusine coracana (L) Gaertn.., tendo esta sido realizada à lanço e incorporada com grade niveladora, no início do mês de setembro. Para garantir o bom desenvolvimento dessa cultura foi aplicada uma dose de $30 \mathrm{~kg} \mathrm{ha}^{-1}$ de nitrogênio, aos 20 dias após a emergência, em todas as parcelas. Foi realizada a irrigação da área promovida no período de ausência de chuvas.

A dessecação do capim-pé-de-galinha foi realizada no período em que as plantas encontravam-se no estádio de florescimento, com glifosato na dose de $5 \mathrm{~L} \mathrm{ha}^{-1}(2.400 \mathrm{~g}$ $\mathrm{ha}^{-1}$ do i.a.). 
A adubação da cultura da soja foi realizada manualmente, aplicando-se o adubo dentro do sulco aberto pela máquina semeadora-adubadora de parcelas, antes da semeadura.

A soja foi semeada no dia 06/12/2001, utilizando-se o cultivar BRS-133, com 20 sementes por metro. As sementes foram tratadas com os fungicidas thiran + thiabendazole $(70+17 \mathrm{~g}$ de i.a. por $100 \mathrm{~kg}$ de semente, respectivamente) e inoculante turfoso (300 g do produto comercial por $100 \mathrm{~kg}$ de semente). Aos 30 e 45 dias após a emergência das plantas aplicaram-se os micronutrientes via foliar, por meio de solução comercial descrita anteriormente.

O controle das plantas daninhas foi realizado com os herbicidas imazaquin na dose de $200 \mathrm{~g} \mathrm{ha}^{-1}$ (140 $\mathrm{g} \mathrm{ha}^{-1}$ de i.a.) e flumetsulan na dose de $0,5 \mathrm{~L} \mathrm{ha}^{-1}\left(60 \mathrm{~g} \mathrm{ha}^{-1} \mathrm{de}\right.$ i.a.) em pré-emergência, e clethodim na dose de $0,33 \mathrm{~L} \mathrm{ha}^{-1}\left(80 \mathrm{~g} \mathrm{ha}^{-1}\right.$ de i.a.) em pósemergência das plantas daninhas. Para controle de pragas, foi necessária a aplicação de Bacillus thuringiensis na dose de $500 \mathrm{~g} \mathrm{ha}^{-1}\left(16 \mathrm{~g} \mathrm{ha}^{-1}\right.$ do i.a.) para controle de lagarta (Anticarsia gemmatalis), e metamidofós na dose de $1 \mathrm{~L} \mathrm{ha}^{-1}$ (600 $\mathrm{g} \mathrm{ha}^{-1}$ do i.a.) para controle de percevejos (Nezara viridula e Piezodorus guildinii). Para prevenir a ocorrência de doenças no final do ciclo da soja, foi utilizado o fungicida carbendazim na dose de $500 \mathrm{~mL} \mathrm{ha}^{-1}$ (250 $\mathrm{mL} \mathrm{ha}^{-1}$ do i.a.)

\subsection{Características Avaliadas}

\subsubsection{Produção de matéria seca, concentração e acúmulo de nutrientes pelo capim- pé-de-galinha}

Foi realizada a coleta da parte aérea do capim-pé-de-galinha, com uma amostra

de $1 \mathrm{~m}^{2}$ de área, de cada parcela experimental, no momento em que 50\% das plantas estavam florescendo e antes da dessecação. Essa amostra foi seca em estufa por 72 horas a $70^{\circ} \mathrm{C}$, e pesada para determinação da massa de matéria seca vegetal. As amostras, após a secagem em estufa, foram moídas em moinho tipo Wiley e encaminhadas para o laboratório de análises químicas do Departamento de Solos e Nutrição de Plantas - 
USP/ESALQ, para determinação das concentrações de N, P, K, Ca, Mg, S, Cu, Fe, Mn e Zn na parte aérea da planta.

A extração de nutrientes pela parte aérea do capim-pé-de-galinha foi determinada através do produto da biomassa produzida por hectare pela concentração de cada nutriente no material vegetal.

\subsubsection{Produção de matéria seca, concentração de nutrientes nos grãos e exportação de nutrientes pela cultura da soja}

Para a avaliação do acúmulo de matéria seca produzida ao longo do ciclo da cultura da soja, foram realizadas sete coletas em estádios fenológicos diferentes: $V_{4}, V_{7}$, $\mathrm{V}_{10} / \mathrm{R}_{2}, \mathrm{R}_{3}, \mathrm{R}_{5.3}, \mathrm{R}_{6}$ e $\mathrm{R}_{7.2}$, de acordo com a escala fenológica de Ferh \& Caviness (1977), traduzida por Câmara (1998). Os estádios citados estão descritos na tabela 4.

Dez plantas foram coletadas em cada estádio citado, procedendo-se a separação da planta em: folhas, caules, vagens e raízes; essas partes foram secas em estufa por 72 horas a $70^{\circ} \mathrm{C}$ e pesadas para determinação da massa de matéria seca.

Amostras dos grãos obtidos da colheita das parcelas, após a secagem em estufa, foram moídas em moinho tipo Wiley e encaminhadas para o laboratório de análises químicas do Departamento de Solos e Nutrição de Plantas - USP/ESALQ, para determinação das concentrações de N, P, K, Ca, Mg, S, Cu, Fe, Mn e Zn. A exportação dos nutrientes foi determinada através do produto da concentração dos elementos presentes nos grãos pela produtividade de grãos. 
Tabela 4. Descrição dos estádios fenológicos vegetativos e reprodutivos da soja utilizados para coleta dos dados experimentais

\begin{tabular}{|c|c|c|}
\hline Símbolo & Denominação & Descrição \\
\hline \multicolumn{3}{|l|}{ Fase Vegetativa } \\
\hline $\mathrm{V}_{4}$ & Quarto nó & Terceiro trifólio aberto \\
\hline $\mathrm{V}_{7}$ & Sétimo nó & Sétimo trifólio aberto \\
\hline $\mathrm{V}_{\mathrm{n}}$ & Enésimo nó & Enésimo trifólio aberto \\
\hline \multicolumn{3}{|c|}{ Fase Reprodutiva } \\
\hline $\mathrm{R}_{2}$ & Florescimento pleno & Maioria dos rácemos com flores abertas \\
\hline $\mathrm{R}_{3}$ & Início da frutificação & Final da floração: vagens com até $0,5 \mathrm{~cm}$ \\
\hline $\mathrm{R}_{5.3}$ & Frutificação & $\begin{array}{l}\text { Maioria das vagens com mais de } 25 \% \text { e } \\
\text { até } 50 \% \text { de granação }\end{array}$ \\
\hline $\mathrm{R}_{6}$ & Final da frutificação & $\begin{array}{l}\text { Maioria das vagens com volume máximo } \\
\text { e plantas verdes }\end{array}$ \\
\hline $\mathrm{R}_{7.2}$ & Maturação fisiológica & $\begin{array}{l}\text { Mais de } 50 \% \text { e até } 75 \% \text { de folhas e vagens } \\
\text { amarelas }\end{array}$ \\
\hline
\end{tabular}

Fonte: Fehr e Caviness, adaptado por Câmara (1998).

\subsubsection{Produtividade agrícola da cultura da soja}

Para a determinação da produtividade agrícola da cultura da soja foram colhidas seis linhas centrais e medida a massa de grãos de cada parcela, tendo sido esta extrapolada para $\mathrm{kg}$ por hectare, corrigindo-se a umidade para 13\%. A colheita foi realizada no dia 12 de abril de 2002.

\subsection{Análise estatística}

Para avaliar o efeito dos tratamentos sobre as características avaliadas, os dados coletados foram submetidos à análise de variância ao nível de 5\% de significância. A 
partir desta análise utilizou-se o teste de Tukey para comparação de médias, ao nível de $5 \%$ de probabilidade. O estudo foi realizado com o auxílio do pacote estatístico SAS.

Para a avaliação do acúmulo de matéria seca na cultura da soja foram analisados os dados de cada estádio fenológico distintamente. 


\section{RESULTADOS E DISCUSSÃO}

\subsection{Considerações sobre a precipitação pluvial e a temperatura do ar durante o período de experimentação}

Em experimentação agronômica em condições de campo, torna-se essencial o acompanhamento da evolução dos principais elementos do clima que interferem

diretamente no desenvolvimento e produtividade das plantas, principalmente, a precipitação pluvial e a temperatura do ar.

A figura 1 ilustra as condições climáticas do período experimental, servindo como subsídio para uma avaliação mais adequada dos resultados apresentados posteriormente. Os valores de precipitação foram obtidos com a coleta diária do volume de chuva captado em um pluviômetro $\left(100 \mathrm{~cm}^{2}\right.$ de área) posicionado junto à área do experimento, enquanto que os valores de temperatura média são dados da estação meteorológica do Departamento de Ciências Exatas, da USP/ESALQ, para a cidade de Piracicaba-SP.

O volume total coletado de precipitação durante os 121 dias do ciclo cultural da soja foi de $637 \mathrm{~mm}$. Fageria (1997) comenta que o uso de água pela soja pode oscilar de 450 a 825 mm onde a estação de crescimento varia entre 100 dias, em baixas altitudes, a 190 dias, em altas altitudes.

É possível notar a ocorrência de um período de adversidade climática, entre a segunda quinzena de fevereiro e a primeira quinzena de março, quando houve um decréscimo acentuado da precipitação (veranico), com valores totais de 13,5 $\mathrm{mm}$ e 30,9 mm, respectivamente, associado à elevação da temperatura média, com valores de 24,9 
e $24,4{ }^{\circ} \mathrm{C}$ na primeira e segunda quinzena de março, respectivamente, tendo ocorrido temperaturas diárias máximas de $34^{\circ} \mathrm{C}$.

A ausência de chuva coincidiu com os estádios fenológicos $R_{5}$ e $R_{6}$ da cultura da soja, que representam o momento de enchimento de vagens, ou seja, o intenso acúmulo de matéria seca pelos grãos, em função da translocação de fotoassimilados (Câmara, 2000).

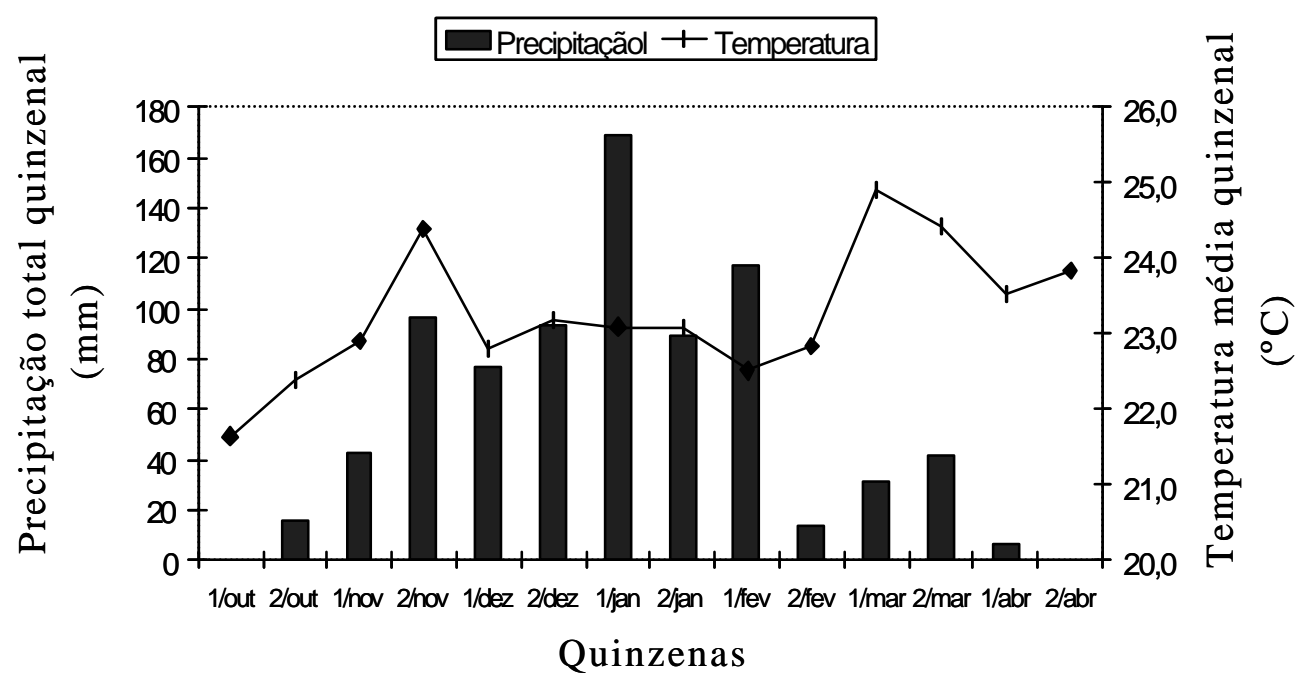

Figura 1 - Valores médios de precipitação total e temperatura média do ar observados na área experimental, para as quinzenas correspondentes ao período de outubro de 2001 a abril de 2002.

Entretanto, essas condições adversas ocorreram de forma geral em toda a área experimental, de maneira que todos os tratamentos foram uniformemente atingidos por tais condições. Mesmo assim, e considerando-se o primeiro cultivo de soja na área, destacam-se os níveis de produtividade alcançados, creditando-se tais produtividades, à boa capacidade de armazenamento de água pelo solo da área experimental. 


\subsection{Produtividade de matéria seca do capim-pé-de-galinha}

A produtividade de matéria seca (PMS) do capim-pé-de-galinha, em função dos tratamentos aplicados, pode ser observada na tabela 5 e na figura 2.

Tabela 5. Valores médios de produção de matéria seca do capim-pé-de-galinha (PMS) observados no estádio de florescimento

\begin{tabular}{|c|c|c|c|}
\hline \multicolumn{3}{|c|}{ Tratamentos } & \multirow{2}{*}{$\begin{array}{c}\text { PMS } \\
\left(\mathrm{kg} \mathrm{ha}^{-1}\right)\end{array}$} \\
\hline & Capim-pé-de-galinha & Soja & \\
\hline $\mathrm{T} 1$ & Testemunha $^{1} 1$ & $\mathrm{ATR}^{2}$ & $3.712^{3} \mathrm{ab}$ \\
\hline $\mathrm{T} 2$ & $50 \%$ de $\mathrm{P}_{2} \mathrm{O}_{5}$ da ATR & ATR (-) $50 \%$ de $\mathrm{P}_{2} \mathrm{O}_{5}$ & $4.776 \mathrm{ab}$ \\
\hline $\mathrm{T} 3$ & $50 \%$ de $\mathrm{K}_{2} \mathrm{O}$ da ATR & ATR (-) $50 \%$ de $\mathrm{K}_{2} \mathrm{O}$ & $4.800 \mathrm{ab}$ \\
\hline $\mathrm{T} 4$ & $100 \%$ de $\mathrm{P}_{2} \mathrm{O}_{5}$ da ATR & $\operatorname{ATR}(-) 100 \%$ de $\mathrm{P}_{2} \mathrm{O}_{5}$ & $4.967 \mathrm{ab}$ \\
\hline T5 & $100 \%$ de $\mathrm{K}_{2} \mathrm{O}$ da ATR & ATR (-) $100 \%$ de $\mathrm{K}_{2} \mathrm{O}$ & $5.142 \mathrm{ab}$ \\
\hline T6 & $\begin{array}{l}50 \% \text { de } \mathrm{P}_{2} \mathrm{O}_{5} \text { da ATR } \\
50 \% \text { de } \mathrm{K}_{2} \mathrm{O} \text { da ATR }\end{array}$ & $\begin{array}{l}\text { ATR (-) } 50 \% \text { de } \mathrm{P}_{2} \mathrm{O}_{5} \\
\text { ATR (-) } 50 \% \text { de } \mathrm{K}_{2} \mathrm{O}\end{array}$ & $5.210 \mathrm{ab}$ \\
\hline $\mathrm{T} 7$ & $\begin{array}{c}100 \% \text { de } \mathrm{P}_{2} \mathrm{O}_{5} \text { da ATR } \\
50 \% \text { de } \mathrm{K}_{2} \mathrm{O} \text { da ATR }\end{array}$ & $\begin{array}{c}\text { ATR (-) } 100 \% \text { de } \mathrm{P}_{2} \mathrm{O}_{5} \\
\text { ATR (-) } 50 \% \text { de } \mathrm{K}_{2} \mathrm{O}\end{array}$ & $5.310 \mathrm{ab}$ \\
\hline $\mathrm{T} 8$ & $\begin{array}{l}50 \% \text { de } \mathrm{P}_{2} \mathrm{O}_{5} \text { da ATR } \\
100 \% \text { de } \mathrm{K}_{2} \mathrm{O} \text { da ATR }\end{array}$ & $\begin{array}{l}\text { ATR (-) } 50 \% \text { de } \mathrm{P}_{2} \mathrm{O}_{5} \\
\operatorname{ATR}(-) 100 \% \text { de } \mathrm{K}_{2} \mathrm{O}\end{array}$ & $5.554 \mathrm{ab}$ \\
\hline T9 & $\begin{array}{l}100 \% \text { de } \mathrm{P}_{2} \mathrm{O}_{5} \text { da ATR } \\
100 \% \text { de } \mathrm{K}_{2} \mathrm{O} \text { da ATR }\end{array}$ & $\begin{array}{l}\text { ATR (-) } 100 \% \text { de } \mathrm{P}_{2} \mathrm{O}_{5} \\
\text { ATR (-) } 100 \% \text { de } \mathrm{K}_{2} \mathrm{O}\end{array}$ & $6.375 \mathrm{a}$ \\
\hline $\mathrm{T} 10$ & $\begin{array}{l}\text { ATR (-) } 100 \% \text { de } \mathrm{P}_{2} \mathrm{O}_{5} \\
\operatorname{ATR}(-) 100 \% \text { de } \mathrm{K}_{2} \mathrm{O}\end{array}$ & $\begin{array}{l}100 \% \text { de } \mathrm{P}_{2} \mathrm{O}_{5} \text { da ATR } \\
100 \% \text { de } \mathrm{K}_{2} \mathrm{O} \text { da ATR }\end{array}$ & $2.901 \mathrm{~b}$ \\
\hline $\mathrm{T} 11$ & ATR & Testemunha 1 & $5.348 \mathrm{ab}$ \\
\hline $\mathrm{T} 12$ & Testemunha $2^{4}$ & Testemunha 2 & $3.488 \mathrm{~b}$ \\
\hline Média & & & 4.799 \\
\hline $\mathrm{P}>\mathrm{F}$ & & & $* *$ \\
\hline C.V. $(\%)$ & & & 19,17 \\
\hline
\end{tabular}

\footnotetext{
Test.=Testemunha (sem adubação);

${ }^{2}$ ATR = Adubação Total Recomendada;

${ }^{3}$ Médias seguidas por letras distintas diferem entre si pelo teste de Tukey a 5\%;

${ }^{4}$ Sistema não adubado.
} 
Nota-se o efeito positivo do acréscimo de nutrientes sobre a produção de matéria seca do capim-pé-de-galinha. Nota-se ainda, que esse efeito positivo também é progressivo na medida em que crescem os níveis de adubação antecipada no capim-péde-galinha, até o tratamento 9, com a antecipação total da adubação de base. Neste tratamento, constatou-se o maior valor numérico de produção de matéria seca do capimpé-de-galinha $\left(6.375 \mathrm{~kg} \mathrm{ha}^{-1}\right)$, significativamente superior às produções proporcionadas pelas ausências tanto da adubação antecipada (tratamento 10 com $2.901 \mathrm{~kg} \mathrm{ha}^{-1}$ ), como pela ausência total de adubação no sistema de produção (tratamento 12 com $3.488 \mathrm{~kg}$ $\left.\mathrm{ha}^{-1}\right)$.

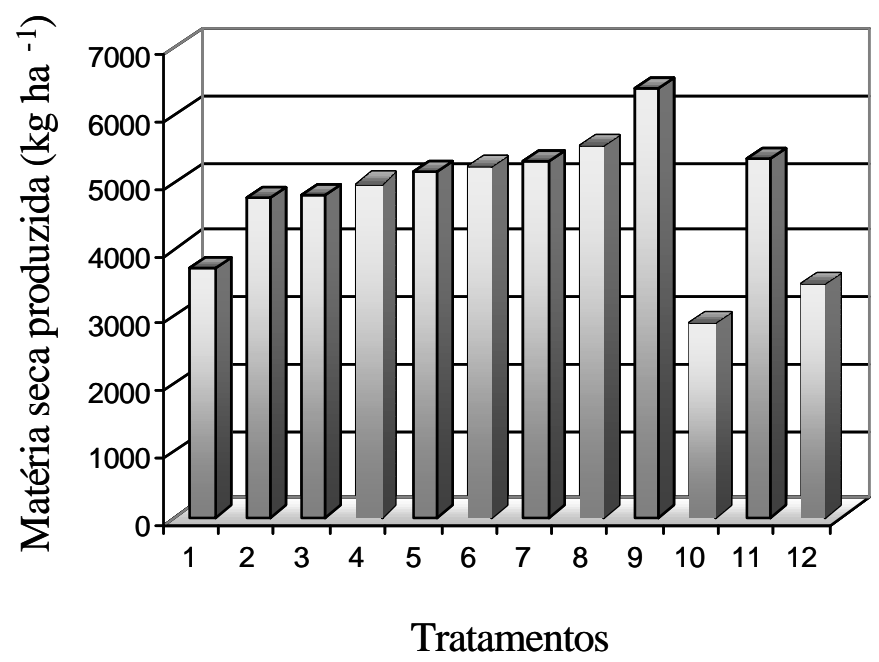

Figura 2 - Matéria seca produzida pelo capim-péde-galinha em função dos tratamentos aplicados.

Na figura 2, é possível visualizar o efeito positivo do acréscimo de nutrientes com a adubação sobre a PMS do capim-pé-de-galinha, indicando que as quantidades de $\mathrm{P}_{2} \mathrm{O}_{5}$ e $\mathrm{K}_{2} \mathrm{O}$ aplicadas promoveram o incremento de matéria seca acumulada pela planta. Esse dado corrobora com o de Pilane et al. (1997), que obteve aumento na fitomassa produzida com a aplicação de nitrogênio e fósforo. 
De maneira geral, os valores observados para a produção de matéria seca do capim-pé-de-galinha são inferiores aos obtidos na Índia por Rao et al. (1990), Saini et al. (1996), Subba Rao (1996), Pilane et. al. (1997), Singh e Arya (1997), que relataram produtividades de 7.400 a $12.600 \mathrm{~kg}$ de matéria seca por hectare.

De acordo com a recomendação de Denardin \& Kochhann (1993) e Darolt (1998), de que as espécies para uso no sistema de plantio direto como plantas de cobertura devem estar dentro de um limite de 6 a $12 \mathrm{t} \mathrm{h}^{-1}$, a fim de que haja o bom desenvolvimento do sistema, pode-se assumir que a espécie Eleusine coracana (L.) Gaertn., cultivada em solo de boa fertilidade, atende adequadamente a essa recomendação.

\subsection{Concentração e acúmulo de macro e micronutrientes na parte aérea do capim- pé-de-galinha}

Por ser uma cultura recentemente introduzida no Brasil, a fim de ser utilizada no sistema de plantio direto e na integração lavoura-pecuária, faz-se valiosa a apresentação da concentração e acúmulo de macro e micronutrientes encontrados na parte aérea do capim-pé-de-galinha, por ocasião do florescimento.

As médias dos tratamentos, para cada nutriente avaliado, podem ser observadas nas tabelas $6,7,8$ e 9 .

A análise dos dados revelou ter havido uma resposta significativa da adubação antecipada na concentração de alguns nutrientes, significando que o capim-pé-degalinha se aproveitou da disponibilidade desses elementos.

$\mathrm{O}$ nitrogênio teve absorção equivalente para todos os tratamentos. $\mathrm{E}$ a concentração média encontrada, 19,48 $\mathrm{g} \mathrm{kg}^{-1}$, é superior à mencionada por Reddy et al. (1986) de $6,3 \mathrm{~g} \mathrm{~kg}^{-1}$. A aplicação de $30 \mathrm{~kg}$ de $\mathrm{N} \mathrm{ha}^{-1}$ em todos os tratamentos pode ter favorecido a homogeneidade das médias encontradas. 
Tabela 6. Valores médios para a concentração de macronutrientes na parte aérea do capim-pé-de-galinha observados no estádio de florescimento

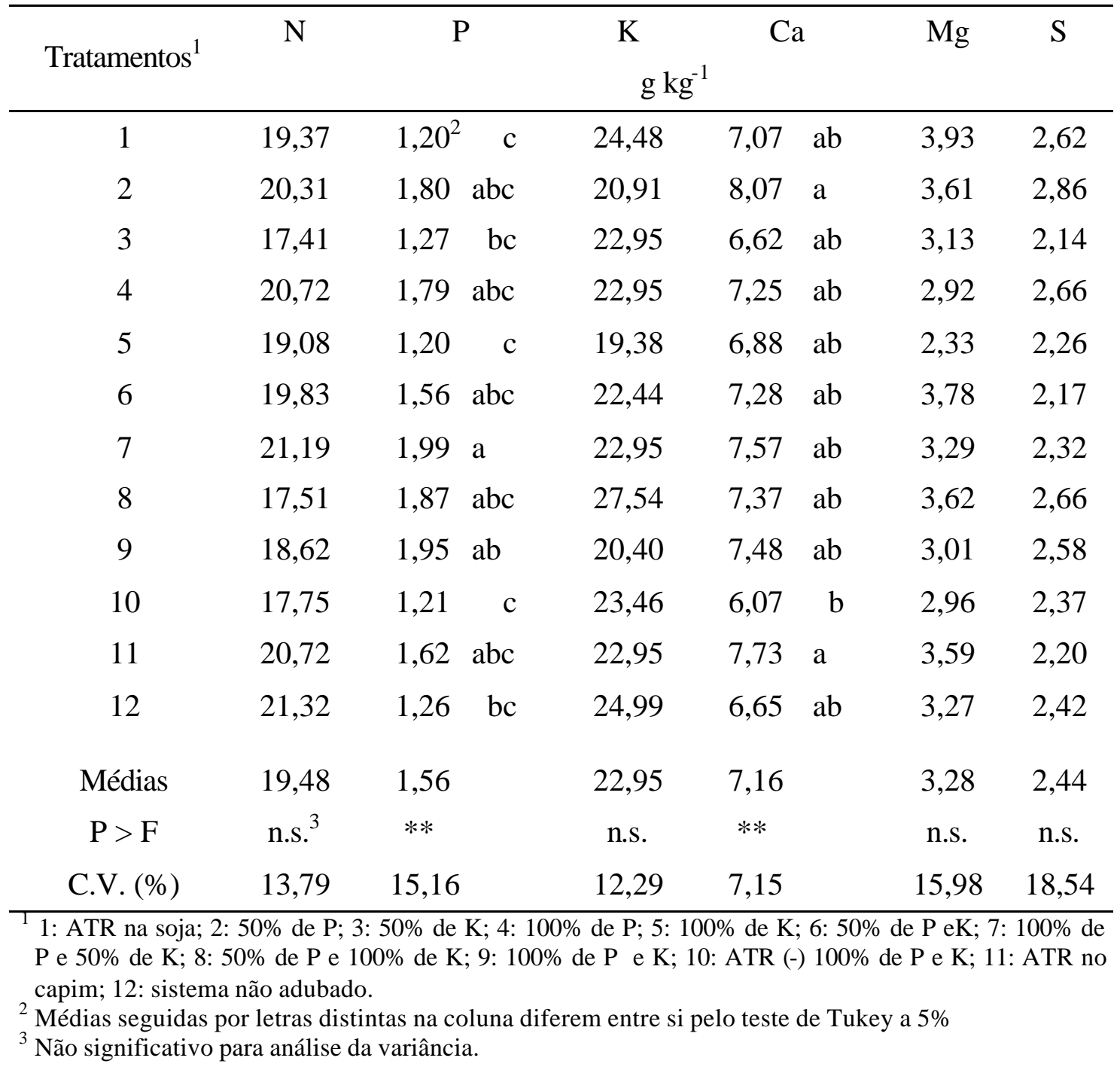

A concentração de fósforo na parte aérea da planta apresentou diferença significativa. Os tratamentos que apresentaram maior concentração são os que receberam $\mathrm{P}_{2} \mathrm{O}_{5}$, mostrando que o capim absorveu o fósforo disponibilizado no solo pela adubação. Rossi \& Monteiro (1999) obtiveram o acréscimo na concentração de fósforo na parte aérea de capim-braquiária, em função da aplicação de doses crescentes do elemento. Os autores comentam que há correlação entre a produção de matéria seca, a concentração e o acúmulo de fósforo na planta. De acordo com Werner (1986), o 
fósforo desempenha importante papel no desenvolvimento do sistema radicular e no perfilhamento de gramíneas, o que explica o resultado de Monteiro et al. (1995), que cultivando Braquiaria brizantha Stapf. cv. Marandu em solução nutritiva com a omissão de $\mathrm{P}$, obtiveram plantas raquíticas e sem perfilhos laterais.

A concentração de potássio pelo capim não apresentou diferença significativa, indicando que, possivelmente, o teor de $\mathrm{K}$ no solo era suficientemente elevado para suprir as exigências das plantas. Monteiro et al. (1995) comentam não ter obtido redução na produção de matéria seca e no perfilhamento da Braquiaria brizantha Stapf. cv. Marandu cultivada em solução nutritiva com omissão de K.

A concentração de cálcio apresentou diferença significativa, estando as maiores médias associadas às maiores concentrações de fósforo. Possivelmente, o cálcio presente no superfosfato triplo, utilizado na adubação das parcelas, favoreceu a nutrição da planta. Todavia, a maior absorção de fósforo poderia ocasionar uma melhoria no crescimento radicular, com mais energia, favorecendo a absorção e o aproveitamento do cálcio. As concentrações de magnésio e enxofre não foram significativamente alteradas em função dos tratamentos empregados.

A concentração dos elementos cobre, ferro e manganês não foi alterada, apesar da adubação foliar ter sido realizada nos tratamentos 10 e 11. Contudo, a adubação foliar elevou significativamente a concentração de zinco na parte aérea da planta, em relação aos tratamentos que não a receberam.

Os dados obtidos para a concentração de nutrientes no capim-pé-de-galinha mostram que as concentrações de nitrogênio, potássio, magnésio, cobre e manganês são superiores em relação às concentrações dos mesmos nutrientes nas plantas de milheto e sorgo obtidas por Moraes (2001). 
Tabela 7. Valores médios para a concentração de micronutrientes na parte aérea do capim-pé-de-galinha obtidos no estádio de florescimento

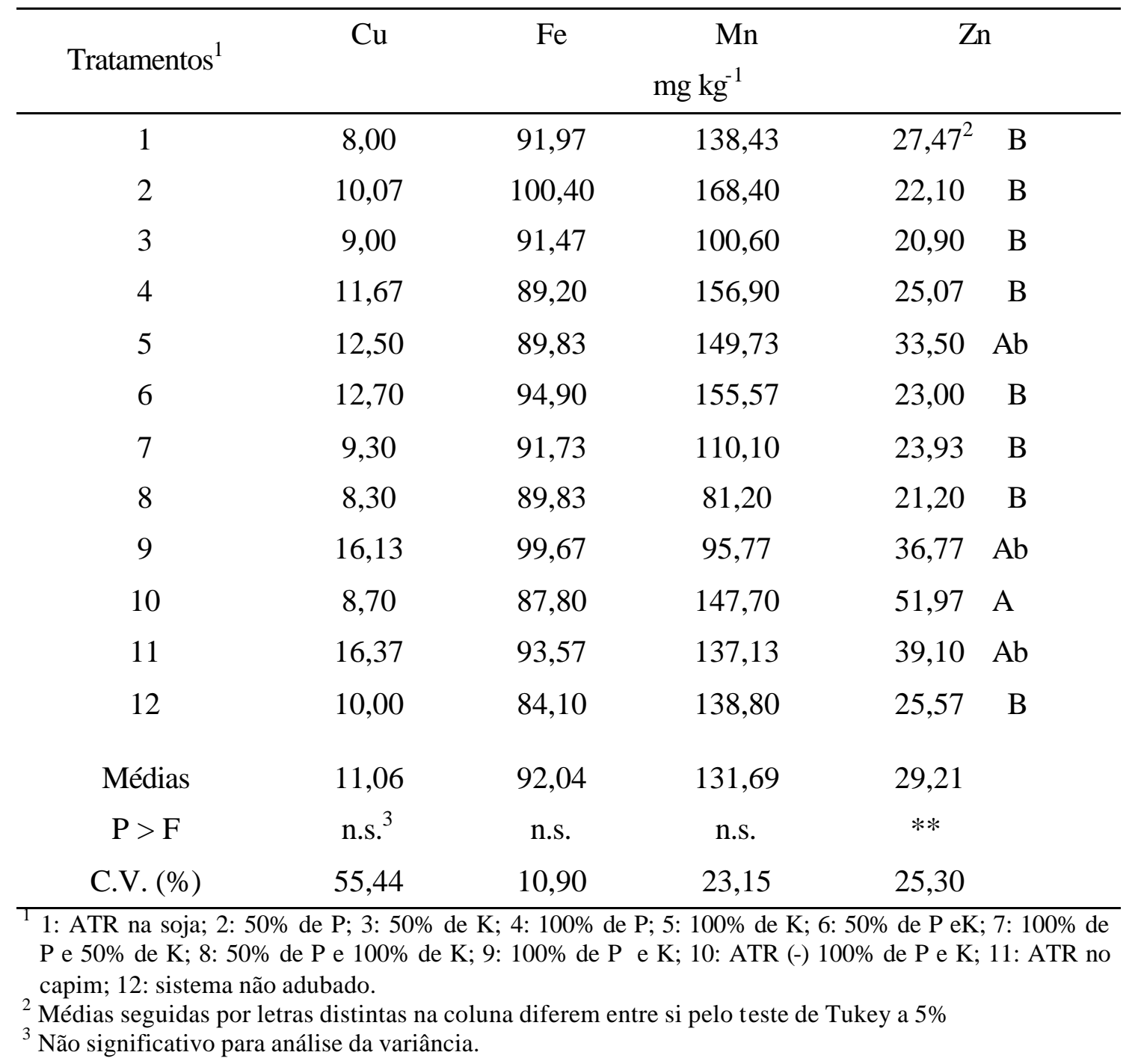

Os dados apresentados nas tabelas 8 e 9 referem-se à quantidade acumulada de nutrientes na parte aérea do capim-pé-de-galinha por ocasião do manejo (dessecação), no estádio de florescimento. 
Tabela 8. Acúmulo de macronutrientes na matéria seca do capim-pé-de-galinha observado no estádio de florescimento

\begin{tabular}{|c|c|c|c|c|c|c|c|}
\hline Tratamentos 1 & \multicolumn{7}{|c|}{$\mathrm{kg} \mathrm{ha}^{-1}$} \\
\hline 1 & 71,83 & $4,46^{2}$ & $\mathrm{c}$ & 90,95 & $26,26 \quad b c$ & 14,62 & 9,71 \\
\hline 2 & 96,98 & 8,66 & $\mathrm{abc}$ & 99,32 & 38,34 abc & 17,43 & 13,33 \\
\hline 3 & 84,45 & 6,07 & $\mathrm{bc}$ & 108,75 & $32,19 \mathrm{abc}$ & 15,27 & 10,22 \\
\hline 4 & 100,10 & 8,41 & $a b c$ & 112,85 & $35,82 \mathrm{abc}$ & 14,18 & 13,01 \\
\hline 5 & 98,65 & 6,13 & $\mathrm{bc}$ & 99,18 & $35,35 \mathrm{abc}$ & 11,95 & 11,80 \\
\hline 6 & 106,95 & 8,20 & $\mathrm{abc}$ & 117,28 & $38,20 \mathrm{abc}$ & 20,20 & 11,72 \\
\hline 7 & 112,19 & 10,51 & $a b$ & 120,95 & $40,01 \mathrm{ab}$ & 17,58 & 12,33 \\
\hline 8 & 97,93 & 10,49 & $a b$ & 154,15 & $41,18 \mathrm{ab}$ & 20,12 & 14,34 \\
\hline 9 & 116,69 & 12,60 & $\mathrm{a}$ & 131,90 & $47,52 \mathrm{a}$ & 18,55 & 16,42 \\
\hline 10 & 51,57 & 3,52 & $\mathrm{c}$ & 68,24 & $17,61 \quad \mathrm{c}$ & 8,62 & 6,87 \\
\hline 11 & 109,08 & 8,58 & $a b c$ & 124,04 & $40,97 \mathrm{ab}$ & 18,97 & 11,63 \\
\hline 12 & 74,76 & 4,39 & $\mathrm{c}$ & 87,52 & $23,11 \quad b c$ & 11,47 & 8,53 \\
\hline Médias & 93,43 & 7,67 & & 109,59 & 34,71 & 15,75 & 11,66 \\
\hline $\mathrm{P}>\mathrm{F}$ & n.s. ${ }^{3}$ & $* *$ & & n.s. & $* *$ & n.s. & n.s. \\
\hline C.V. (\%) & 25,11 & 24,85 & & 23,82 & 20,52 & 26,78 & 26,89 \\
\hline
\end{tabular}

T. 1: ATR na soja; 2: 50\% de P; 3: 50\% de K; 4: 100\% de P; 5: 100\% de K; 6: 50\% de P eK; 7: 100\% de P e 50\% de K; 8: 50\% de P e 100\% de K; 9: 100\% de P e K; 10: ATR (-) 100\% de P e K; 11: ATR no capim; 12: sistema não adubado.

${ }^{2}$ Médias seguidas por letras distintas na coluna diferem entre si pelo teste de Tukey a 5\%

${ }^{3}$ Não significativo para análise da variância.

Não houve resposta significativa da análise de variância para a quantidade acumulada de nitrogênio, potássio, magnésio, enxofre, cobre, manganês e zinco. Houve resposta significativa da quantidade acumulada de fósforo, cálcio e ferro.

Analisando-se os dados da tabela 8, verifica-se que as maiores médias de acúmulo de fósforo coincidem com as maiores concentrações do nutriente na planta, bem como para o cálcio.

Esse maior acúmulo de $\mathrm{P}$ e Ca na fitomassa pode ser um indicativo de que o teor desses nutrientes era fator limitante para a produtividade de matéria seca. 
Tabela 9. Acúmulo de micronutrientes na matéria seca do capim-pé-de-galinha observado no estádio de florescimento

\begin{tabular}{|c|c|c|c|c|c|}
\hline \multirow{2}{*}{$\begin{array}{c}\text { Tratamentos }^{1} \\
1\end{array}$} & $\mathrm{Cu}$ & \multicolumn{2}{|c|}{$\mathrm{Fe}$} & \multirow{2}{*}{\begin{tabular}{c}
\multicolumn{1}{c}{$\mathrm{Mn}$} \\
518,68
\end{tabular}} & $\mathrm{Zn}$ \\
\hline & 29,56 & $342,87^{2}$ & bc & & 102,58 \\
\hline 2 & 50,65 & 476,70 & $a b c$ & 843,30 & 106,19 \\
\hline 3 & 40,21 & 427,38 & $a b c$ & 470,27 & 99,18 a \\
\hline 4 & 58,13 & 437,67 & $a b c$ & 734,25 & 122,38 \\
\hline 5 & 69,39 & 458,92 & $a b c$ & 774,16 & 174,41 \\
\hline 6 & 62,86 & 494,09 & $\mathrm{a}$ & 835,93 & 122,15 \\
\hline 7 & 49,80 & 485,78 & $a b$ & 580,78 & 126,78 \\
\hline 8 & 47,65 & 492,70 & $a b$ & 472,18 & 117,14 \\
\hline 9 & 106,78 & 633,20 & $\mathrm{a}$ & 596,33 & 231,67 \\
\hline 10 & 25,35 & 254,50 & $\mathrm{c}$ & 427,10 & 151,06 \\
\hline 11 & 84,15 & 493,27 & $a b$ & 732,31 & 211,55 \\
\hline 12 & 33,76 & 292,82 & $\mathrm{bc}$ & 472,42 & 89,06 a \\
\hline Médias & 54,86 & 440,83 & & 621,48 & 137,85 \\
\hline $\mathrm{P}>\mathrm{F}$ & n.s. ${ }^{3}$ & $* *$ & & n.s. & $*$ \\
\hline C.V. (\%) & 79,28 & 17,117 & & 34,48 & 35,87 \\
\hline
\end{tabular}

T1: ATR na soja; 2: 50\% de P; 3: 50\% de K; 4: 100\% de P; 5: 100\% de K; 6: 50\% de P eK; 7: 100\% de P e 50\% de K; 8: 50\% de P e 100\% de K; 9: 100\% de P e K; 10: ATR (-) 100\% de P e K; 11: ATR no capim; 12: sistema não adubado.

${ }_{3}^{2}$ Médias seguidas por letras distintas na coluna diferem entre si pelo teste de Tukey a 5\%

${ }^{3}$ Não significativo para análise da variância.

Para a quantidade de zinco acumulada, apesar da análise de variância ter mostrado diferença significativa, o teste de comparação de médias utilizado não detectou diferença entre os tratamentos.

A diferença observada no acúmulo de ferro acompanhou a produtividade de matéria seca.

Atenta-se para as quantidades de nitrogênio e potássio acumuladas por tonelada de matéria seca produzida pelo capim-pé-de-galinha (tabela 8), ou seja, 19,5 e 22,83 kg $\mathrm{t}^{-1}$, respectivamente. Moraes (2001) apresentou valores de $\mathrm{N}$ e $\mathrm{K}$ referentes à uma 


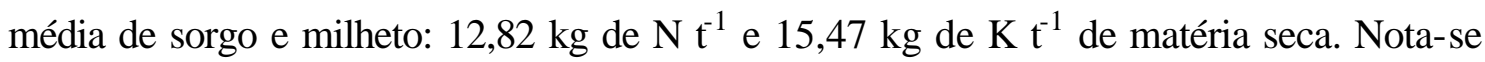
que as quantidades acumuladas de $\mathrm{N}$ e $\mathrm{K}$ por tonelada de MS produzida pelo campimpé-de-galinha são maiores que as médias acumuladas pelo sorgo e milheto.

Com base nos resultados obtidos neste trabalho, pode-se afirmar que a ordem decrescente da média de nutrientes extraídos pela cultura do capim-pé-de-galinha foi $\mathrm{K}$ $(109,5)>\mathrm{N}(93,4)>\mathrm{Ca}(34,7)>\mathrm{Mg}(15,75)>\mathrm{S}(11,6)>\mathrm{P}(7,7)>\mathrm{Mn}(0,621)>\mathrm{Fe}$ $(0,440)>\mathrm{Zn}(0,137)>\mathrm{Cu}(0,054), \mathrm{em} \mathrm{kg} \mathrm{ha}{ }^{-1}$.

\subsection{Acúmulo de matéria seca da soja}

Os valores médios de matéria seca observados durante o ciclo fenológico da soja, em função dos tratamentos, podem ser observados na tabela 10.

A análise dos referidos dados constatou que em nenhum dos estádios fenológicos analisados houve diferença significativa na massa de matéria seca produzida, ou seja, os tratamentos utilizados não causaram efeito nessa característica observada.

A adubação das parcelas experimentais na semeadura da soja foi, gradativamente, sendo reduzida, conforme a antecipação para o capim-pé-de-galinha. De modo que, por exemplo, as parcelas de soja do tratamento 1 receberam a adubação completa e acumularam, em média, $1,177 \mathrm{~kg} \mathrm{~m} \mathrm{~m}^{2}$ de matéria seca total. Comparado-se o tratamento 1 com os tratamentos 11 e 12, que receberam zero de $\mathrm{P}$ e K na adubação de base, devido a total antecipação, e que produziram 1,052 e $0,811 \mathrm{~kg} \mathrm{~m}{ }^{2}$ de matéria seca total, percebe-se que não houve diferença entre os valores.

A matéria seca total da planta mostrou valores crescentes ao longo de todo o ciclo da cultura, atingindo o ponto de maior acúmulo no estádio $\mathrm{R}_{\boldsymbol{g}}$, com $9.350 \mathrm{~kg}$ de MS ha ${ }^{-1}$, e mantendo-se estável até o estádio R.2. A maior taxa de crescimento diário $\left(\mathrm{TCC}=\mathrm{dMS} / \mathrm{dt}\right.$ ) foi verificada entre os estádios $\mathrm{R}_{3}$ e $\mathrm{R}_{5.3}$, com 156,4 kg de MS ha ${ }^{-1}$ $\mathrm{dia}^{-1}$. Este valor está próximo aos valores mensurados por Hanway e Weber (1971b). 
Tabela 10. Valores médios de matéria seca em plantas de soja, cultivar BRS-133, conduzida sobre a palhada de Eleusine coracana (L.) Gaertn., observados nos estádios fenológicos $\mathrm{V}_{4}, \mathrm{~V}_{7}, \mathrm{~V}_{10} / \mathrm{R}_{2}, \mathrm{R}_{3}, \mathrm{R}_{5.3}, \mathrm{R}_{6}$ e $\mathrm{R}_{7.2}$

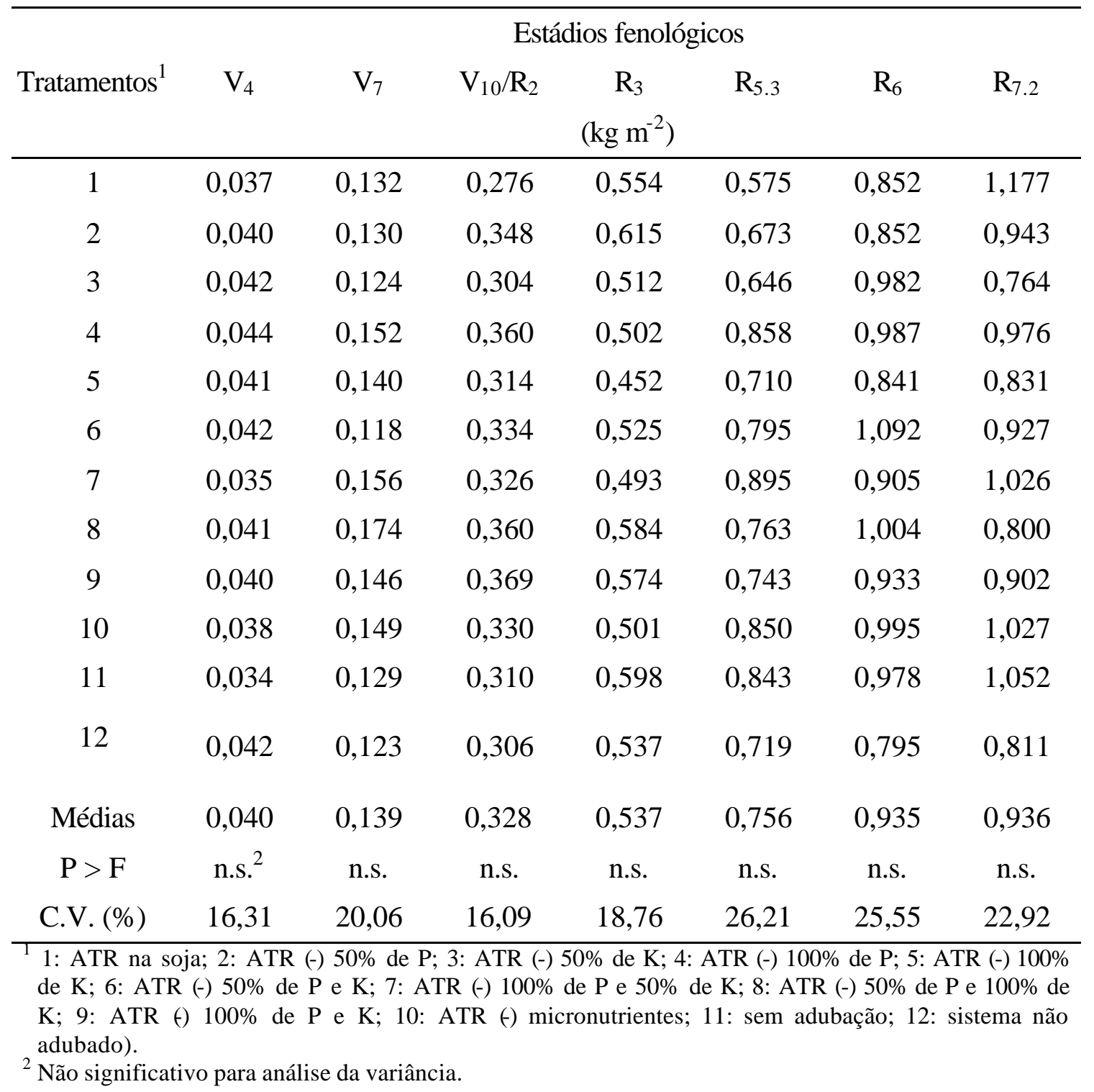

As taxas médias de crescimento obtidas para cada estádio fenológico amostrado foram: $70,7 \mathrm{~kg} \mathrm{~m}^{-2} \mathrm{dia}^{-1} \mathrm{em} \mathrm{V}_{7} ; 135,0 \mathrm{~kg} \mathrm{~m}^{-2} \mathrm{dia}^{-1}$ em V $\mathrm{V}_{10} / \mathrm{R}_{2} ; 149,0 \mathrm{~kg} \mathrm{~m}^{-2} \mathrm{dia}^{-1} \mathrm{em} \mathrm{R}$; $156,0 \mathrm{~kg} \mathrm{~m}^{-2} \mathrm{dia}^{-1}$ em $\mathrm{R}_{5.3}$; e $128,0 \mathrm{~kg} \mathrm{~m}^{-2} \mathrm{dia}^{-1}$ em $\mathrm{R}_{6}$. Peixoto (1998) obteve, para o cultivar IAC-17, semeado em época normal sob três densidades, taxas máximas de crescimento da cultura de: $146,0 \mathrm{~kg} \mathrm{~m}^{-2} \mathrm{dia}^{-1}$, aos 77 dias após a emergência, com 10 plantas $\mathrm{m}^{-1} ; 174,4 \mathrm{~kg} \mathrm{~m}^{-2} \mathrm{dia}^{-1}$, aos 53 dias após a emergência, com 20 plantas $\mathrm{m}^{-1}$; e 
186,6 $\mathrm{kg} \mathrm{m}^{-2}$ dia $^{-1}$, aos 66 dias após a emergência, com 30 plantas $\mathrm{m}^{-1}$, concluindo o autor que a taxa de crescimento da cultura decresceu com o incremento na densidade.

O maior acúmulo de matéria seca da parte vegetativa da planta (folhas, caules e raízes) aconteceu próximo ao estádio $R_{5.3}$, quando a planta apresentava $57 \%$ da massa total final, o que corresponde ao mencionado por Mascarenhas (1972).

A associação do acúmulo de matéria seca com a escala fenológica da cultura da soja permite a melhor observação do desempenho da planta, e a facilidade de associações dos parâmetros fisiológicos, como a marcha de absorção de nutrientes.

Foram analisados os valores de matéria seca das folhas, caules, raízes e vagens, e não houve diferença significativa para nenhum dos componentes, em nenhum dos estádios fenológicos, em função dos tratamentos utilizados. $\mathrm{Na}$ tabela 11, são apresentados os valores médios da massa de matéria seca acumulada nos componentes: folhas, caules, raízes e vagens.

Tabela 11. Valores médios de matéria seca acumulada em folhas, caules, raízes e vagens de soja, cultivar BRS-133, conduzida sobre a palhada de Eleusine coracana (L.) Gaertn., observados nos estádios fenológicos $\mathrm{V}_{4}, \mathrm{~V}_{7}, \mathrm{~V}_{10} / \mathrm{R}_{2}$, $\mathrm{R}_{3}, \mathrm{R}_{5.3}, \mathrm{R}_{6}$ e $\mathrm{R}_{7.2}$

\begin{tabular}{|c|c|c|c|c|c|c|c|}
\hline \multirow[b]{2}{*}{ Órgãos } & \multicolumn{7}{|c|}{ Estádios fenológicos } \\
\hline & $\mathrm{V}_{4}$ & $\mathrm{~V}_{7}$ & $\mathrm{~V}_{10} / \mathrm{R}_{2}$ & $\begin{array}{c}\mathrm{R}_{3} \\
\mathrm{~kg} \mathrm{~m}^{-2}\end{array}$ & $\mathrm{R}_{5.3}$ & $\mathrm{R}_{6}$ & $\mathrm{R}_{7.2}$ \\
\hline Folhas & 0,022 & 0,076 & 0,177 & 0,289 & 0,328 & 0,299 & 0,138 \\
\hline Caules & 0,009 & 0,035 & 0,102 & 0,181 & 0,220 & 0,225 & 0,212 \\
\hline Raízes & 0,009 & 0,028 & 0,049 & 0,060 & 0,077 & 0,074 & 0,068 \\
\hline Vagens & - & - & - & 0,007 & 0,131 & 0,338 & 0,519 \\
\hline Total $^{1}$ & 0,040 & 0,139 & 0,328 & 0,537 & 0,756 & 0,935 & 0,936 \\
\hline
\end{tabular}

Nota-se que a matéria seca das folhas apresenta acúmulo gradual, com ponto de máximo em $\mathrm{R}_{5.3}$, decaindo posteriormente, em função da queda acentuada das folhas 
ocorrida no final do ciclo $\left(\mathrm{R}_{7.2}\right)$, chegando a reduzir em $137 \%$ a sua massa em relação ao ponto de maior acúmulo citado.

O acúmulo de matéria seca no caule é acelerado no início do ciclo, apresentando taxas diárias crescentes de crescimento: 18,8; 47,8 e 56,4 $\mathrm{kg} \mathrm{ha}^{-1}$ dia $^{-1}$ entre os estádios de $V_{4}$ a $V_{7}$, de $V_{7}$ a $V_{10} / R_{2}$ e de $V_{10} / R_{2}$ a $R_{3}$, respectivamente. $O$ caule atinge $48 \%$ de sua massa final no estádio $\mathrm{R}_{2}$. Após este estádio a taxa de crescimento é reduzida, caindo para 27,8 $\mathrm{kg} \mathrm{ha}^{-1} \mathrm{dia}^{-1}$ em $\mathrm{R}_{5.3}, 3,5 \mathrm{~kg} \mathrm{ha}^{-1} \mathrm{dia}^{-1}$ em $\mathrm{R}_{6}$, chegando a reduzir sua massa em $9 \mathrm{~kg} \mathrm{ha}^{-1} \mathrm{dia}^{-1}$ no estádio $\mathrm{R}_{\mathbf{7} .2}$. O ponto de maior acúmulo de matéria seca ocorre no estádio $\mathrm{R}_{5.3}$, com massa de $0,220 \mathrm{~kg} \mathrm{~m} \mathrm{~m}^{2}$, mantendo certa estabilidade até o final do ciclo.

As raízes também apresentaram ponto de maior acúmulo de matéria seca no estádio $\mathrm{R}_{5.3}$, com $0,077 \mathrm{~kg} \mathrm{~m} \mathrm{~m}^{2}$, tendo ocorrido intenso ganho de massa nos estádios iniciais de desenvolvimento, com taxa diária de crescimento de 13 a $15 \mathrm{~kg} \mathrm{ha}^{-1} \mathrm{dia}^{-1}$. Nos estádios seguintes há redução na massa das raízes.

As vagens apresentam acréscimo de massa bastante acelerado, com taxas diárias de crescimento de $88,5 \mathrm{~kg} \mathrm{ha}^{-1} \mathrm{dia}^{-1}$, durante o estádio $\mathrm{R}_{5.3}, 147,8 \mathrm{~kg} \mathrm{ha}^{-1} \mathrm{dia}^{-1}$, no estádio $\mathrm{R}_{6}$, e $129,2 \mathrm{~kg} \mathrm{ha}^{-1}$ dia $^{-1}$ no final do ciclo, em $\mathrm{R}_{7.2}$. Entre os estádios $\mathrm{R}_{5.3}$ e $\mathrm{R}_{6}$ há um acréscimo de $158 \%$ na massa de vagens, e entre os estádios $R_{6}$ e $R_{7.2}$ o acréscimo cai para $53 \%$. Esses dados são condizentes com os apresentados por Mascarenhas (1973).

As figuras 3 e 4 ilustram o desempenho característico da curva de acúmulo de matéria seca pela planta de soja ao longo do seu ciclo. Associando-se a descrição das fases do desenvolvimento vegetal das culturas anuais comentada por Goudriaan e Laar (1994), pode-se perceber nessas figuras, três diferentes períodos do desenvolvimento fisiológico da planta: o primeiro período é a fase da emergência $\left(\mathrm{V}_{\mathrm{E}}\right)$ ao florescimento $\left(R_{1}\right)$, que é exponencial $(A)$; o segundo é do final do florescimento $\left(R_{2}\right)$ à granação inicial das vagens $\left(\mathrm{R}_{5}\right)$, que é uma fase linear $(\mathrm{B})$; o terceiro período é da plena granação $\left(R_{6}\right)$ ao início da queda das folhas $\left(R_{7}\right)$, que é a fase de senescência $(C)$. 
Os tratamentos que não tiveram sua adubação antecipada, e que com isso, receberam maior quantidade de $\mathrm{P}$ e $\mathrm{K}$ no sulco de semeadura, não demonstraram melhor nutrição das plantas, o que poderia resultar em plantas com maior acúmulo de matéria seca, se comparadas com plantas submetidas aos tratamentos cuja adubação foi antecipada para o capim-pé-de-galinha. Como os dados revelam, todos os tratamentos apresentaram a mesma curva de acúmulo de MS, o que também demonstra que a antecipação da adubação não promoveu prejuízo às plantas de soja. 

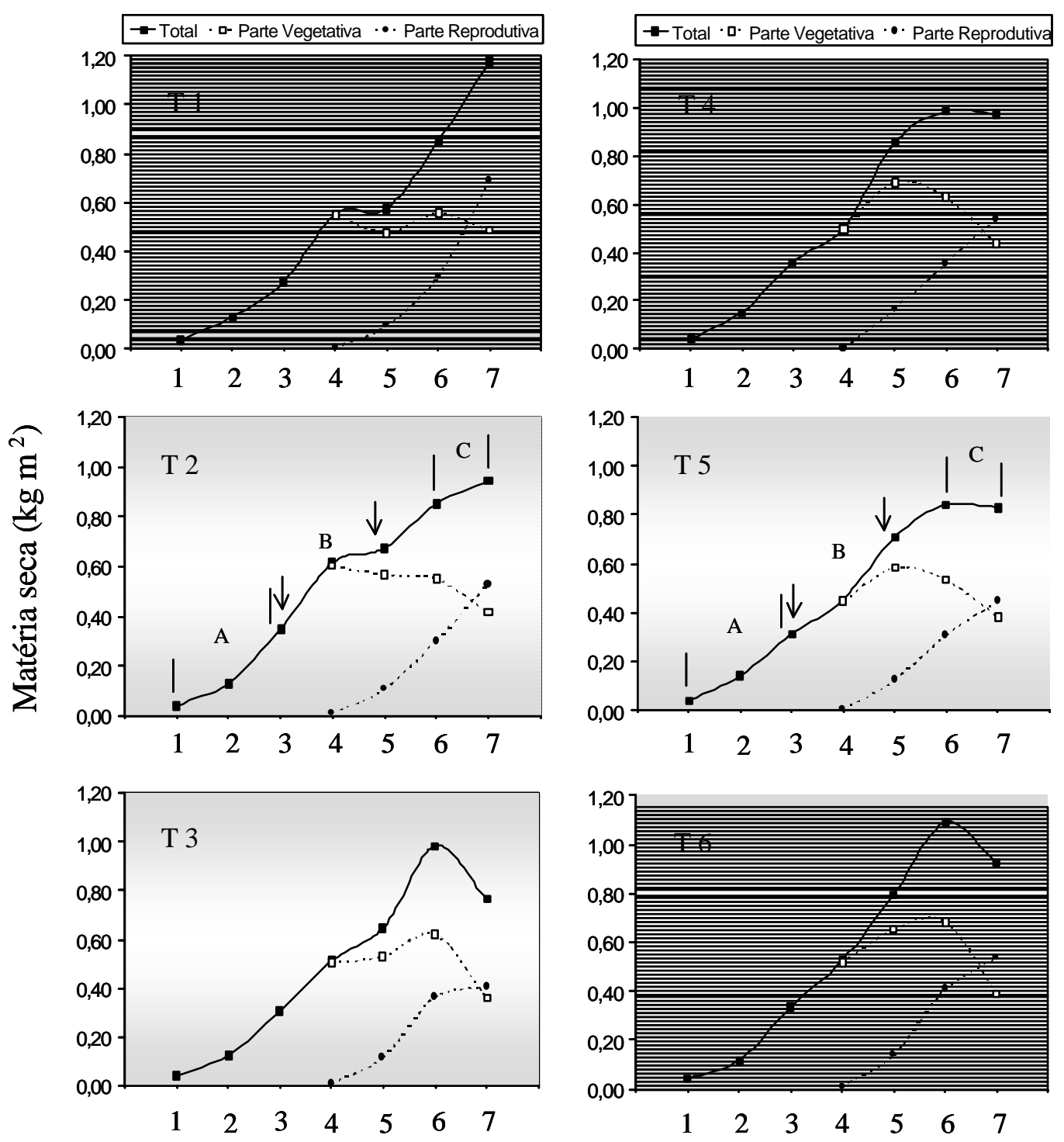

Figura 3 - Evolução da matéria seca produzida pela soja, cultivar BRS-133, semeada diretamente sobre a palhada do capim-pé-de-galinha, submetida aos seis primeiros níveis de parcelamento da adubação de base da soja, aplicados de forma antecipada $\left(1: \mathrm{V}_{4} ; 2: \mathrm{V}_{7} ; 3\right.$ : $\left.\mathrm{V}_{10} / \mathrm{R}_{2} ; 4: \mathrm{R}_{3} ; 5: \mathrm{R}_{5.3} ; 6: \mathrm{R}_{6} ; 7: \mathrm{R}_{7.2}\right)(\mathrm{A}$ - fase exponencial; $\mathrm{B}$ - fase linear; $\mathrm{C}$ - fase senescente). 

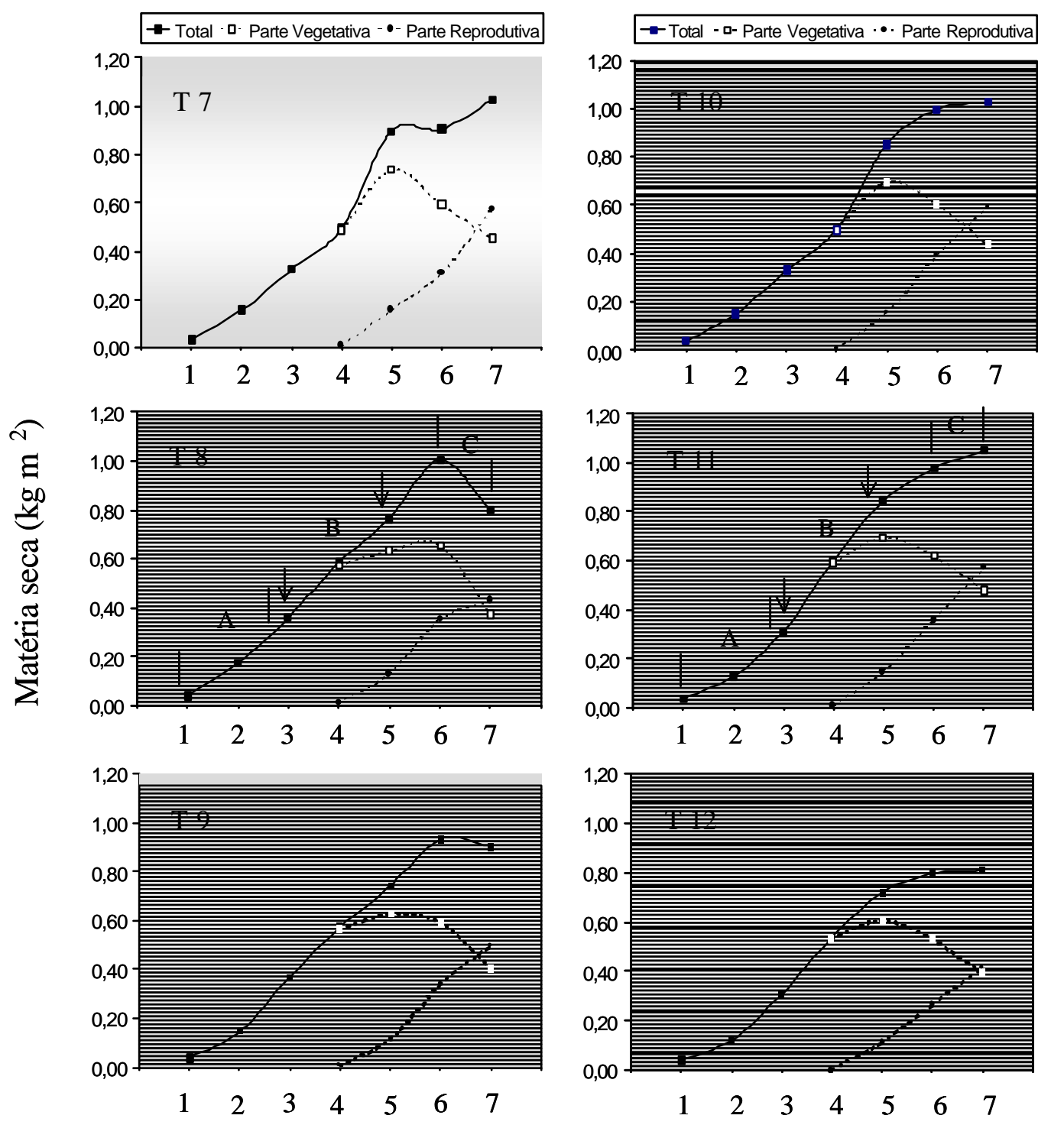

Figura 4 - Evolução da matéria seca produzida pela soja, cultivar BRS-133, semeada diretamente sobre a palhada do capim-pé-de-galinha, submetida aos seis últimos níveis de parcelamento da adubação de base da soja, aplicados de forma antecipada $\left(1: \mathrm{V}_{4} ; 2: \mathrm{V}_{7} ; 3: \mathrm{V}_{10} / \mathrm{R}_{2}\right.$; 4: $\mathrm{R}_{3} ; 5: \mathrm{R}_{5.3} ; 6: \mathrm{R}_{6} ; 7: \mathrm{R}_{7.2}$ ) (A - fase exponencial; $\mathrm{B}$ - fase linear; $\mathrm{C}$ - fase senescente). 


\subsection{Concentração e exportação de nutrientes nos grãos de soja}

Os valores médios das concentrações dos nutrientes nos grãos de soja estão dispostos nas tabelas 12 e 13 .

Tabela 12. Valores médios para a concentração de macronutrientes observados nos grãos de soja, cultivar BRS-133, semeada diretamente sobre a palhada do capim-pé-de-galinha, submetida a doze níveis de parcelamento da adubação de base da soja, aplicados em época antecipada

\begin{tabular}{ccccccc}
\hline Tratamentos ${ }^{1}$ & $\mathrm{~N}$ & $\mathrm{P}$ & $\mathrm{K}$ & $\mathrm{Ca}$ & $\mathrm{Mg}$ & $\mathrm{S}$ \\
\hline 1 & 63,68 & 5,12 & 16,83 & 1,48 & 2,04 & 2,12 \\
2 & 70,68 & 4,96 & 15,30 & 1,50 & 1,94 & 2,11 \\
3 & 64,55 & 4,79 & 16,32 & 1,47 & 2,04 & 2,17 \\
4 & 65,49 & 4,67 & 15,81 & 1,48 & 2,04 & 2,25 \\
5 & 64,75 & 4,57 & 16,32 & 1,55 & 2,05 & 2,18 \\
6 & 66,20 & 4,88 & 15,81 & 1,38 & 1,95 & 2,35 \\
7 & 64,13 & 4,87 & 16,32 & 1,28 & 2,00 & 2,32 \\
8 & 65,48 & 4,84 & 15,30 & 1,55 & 1,80 & 2,47 \\
9 & 70,67 & 4,73 & 15,81 & 1,32 & 1,96 & 2,46 \\
10 & 67,95 & 4,76 & 16,32 & 1,65 & 2,03 & 2,45 \\
11 & 65,84 & 4,58 & 16,83 & 1,35 & 2,07 & 2,35 \\
12 & 62,83 & 3,95 & 15,81 & 1,57 & 1,83 & 2,18 \\
Médias & 66,02 & 4,73 & 16,06 & 1,46 & 1,98 & 2,28 \\
P > F & n.s. & n.s. & n.s. & n.s. & n.s. & n.s. \\
C.V. (\%) & 7,70 & 9,26 & 6,78 & 11,76 & 7,60 & 8,07 \\
\hline
\end{tabular}

1' ATR na soja; 2: ATR (-) 50\% de P; 3: ATR (-) 50\% de K; 4: ATR (-) 100\% de P; 5: ATR (-) 100\% de K; 6: ATR (-) 50\% de P e K; 7: ATR (-) 100\% de P e 50\% de K; 8: ATR (-) 50\% de P e $100 \%$ de K; 9: ATR () 100\% de P e K; 10: ATR () micronutrientes; 11: sem adubação; 12: sistema não adubado).

${ }^{2}$ Não significativo para análise da variância.

A análise da variância dos dados não detectou diferenças significativas para nenhum dos nutrientes analisados. O coeficiente de variação dos dados da concentração 
de macronutrientes apresenta valores adequados para a experimentação agrícola em campo.

Tabela 13. Valores médios para a concentração de micronutrientes observados nos grãos de soja, cultivar BRS-133, semeada diretamente sobre a palhada do capim-pé-de-galinha, submetida a doze níveis de parcelamento da adubação de base da soja, aplicados em época antecipada

\begin{tabular}{|c|c|c|c|c|}
\hline Tratamentos $^{1}$ & $\mathrm{Cu}$ & $\mathrm{Fe}$ & Mn & $\mathrm{Zn}$ \\
\hline 1 & 28,93 & 74,93 & 17,67 & 40,70 \\
\hline 2 & 45,93 & 73,07 & 21,93 & 41,13 \\
\hline 3 & 27,27 & 65,73 & 19,53 & 41,73 \\
\hline 4 & 18,47 & 72,50 & 19,00 & 42,80 \\
\hline 5 & 19,43 & 88,77 & 17,53 & 43,47 \\
\hline 6 & 25,00 & 87,33 & 16,40 & 42,40 \\
\hline 7 & 16,77 & 68,93 & 17,73 & 43,03 \\
\hline 8 & 18,67 & 87,30 & 18,17 & 45,47 \\
\hline 9 & 37,03 & 78,07 & 18,60 & 43,13 \\
\hline 10 & 37,83 & 82,63 & 18,57 & 44,27 \\
\hline 11 & 70,43 & 64,60 & 18,67 & 42,37 \\
\hline 12 & 31,57 & 73,90 & 17,57 & 43,90 \\
\hline Médias & 31,44 & 76,48 & 18,45 & 42,87 \\
\hline $\mathrm{P}>\mathrm{F}$ & n.s. ${ }^{2}$ & n.s. & n.s. & n.s. \\
\hline C.V. (\%) & 78,17 & 13,01 & 13,40 & 6,65 \\
\hline
\end{tabular}

1: ATR na soja; 2: ATR (-) 50\% de P; 3: ATR (-) 50\% de K; 4: ATR (-) 100\% de P; 5: ATR (-) 100\% de K; 6: ATR (-) 50\% de P e K; 7: ATR (-) 100\% de P e 50\% de K; 8: ATR (-) 50\% de P e $100 \%$ de K; 9: ATR () $100 \%$ de $\mathrm{P}$ e K; 10: ATR () micronutrientes; 11: sem adubação; 12: sistema não adubado).

${ }^{2}$ Não significativo para análise da variância.

Mascarenhas et al. (1980) comentam que em solo de baixa fertilidade, há respostas na produção de soja pela aplicação de adubos, mas em solos de média e alta fertilidade, há necessidade de se conhecer o elemento limitante da produção, que pode ser revelado através da análise foliar e das sementes. 
As concentrações médias de $\mathrm{N}, \mathrm{P}, \mathrm{Cu}$ e $\mathrm{Zn}$ obtidas neste trabalho estão acima das apresentadas por Mascarenhas et al. (1980) para 15 variedades de soja. Enquanto as de $\mathrm{K}, \mathrm{Ca}, \mathrm{Mg}, \mathrm{Mn}$ e Fe estão abaixo, a de enxofre é similar à encontrada pelos autores.

Os valores médios da exportação de nutrientes pelos grãos de soja estão apresentados nas tabelas 14 e 15 .

Tabela 14. Valores médios para macronutrientes exportados por tonelada de grãos de soja, cultivar BRS-133, semeada diretamente sobre a palhada do capim-péde-galinha, submetida a doze níveis de parcelamento da adubação de base da soja, aplicados em época antecipada

\begin{tabular}{|c|c|c|c|c|c|c|}
\hline Tratamentos ${ }^{1}$ & \multicolumn{6}{|c|}{$\mathrm{kg} \mathrm{t}^{-1}$} \\
\hline 1 & 63,65 & 5,12 & 16,83 & 1,49 & 2,04 & 2,12 \\
\hline 2 & 70,64 & 4,96 & 15,30 & 1,51 & 1,94 & 2,11 \\
\hline 3 & 64,99 & 4,80 & 16,47 & 1,46 & 2,05 & 2,17 \\
\hline 4 & 65,31 & 4,67 & 15,84 & 1,48 & 2,05 & 2,26 \\
\hline 5 & 64,72 & 4,57 & 16,30 & 1,54 & 2,05 & 2,18 \\
\hline 6 & 66,17 & 4,89 & 15,79 & 1,38 & 1,95 & 2,35 \\
\hline 7 & 64,29 & 4,89 & 16,31 & 1,29 & 2,00 & 2,32 \\
\hline 8 & 65,48 & 4,82 & 15,31 & 1,55 & 1,80 & 2,47 \\
\hline 9 & 70,58 & 4,73 & 15,81 & 1,32 & 1,96 & 2,46 \\
\hline 10 & 67,78 & 4,77 & 16,31 & 1,64 & 2,03 & 2,45 \\
\hline 11 & 65,68 & 4,60 & 16,83 & 1,35 & 2,06 & 2,35 \\
\hline 12 & 62,86 & 3,96 & 15,79 & 1,57 & 1,83 & 2,18 \\
\hline Médias & 66,01 & 4,73 & 16,08 & 1,47 & 1,98 & 2,28 \\
\hline $\mathrm{P}>\mathrm{F}$ & n.s. ${ }^{2}$ & n.s. & n.s. & n.s. & n.s. & n.s. \\
\hline C.V. $(\%)$ & 8,77 & 11,41 & 9,60 & 14,06 & 10,46 & 8,52 \\
\hline
\end{tabular}

T1: ATR na soja; 2: ATR (-) 50\% de P; 3: ATR (-) 50\% de K; 4: ATR (-) 100\% de P; 5: ATR (-) 100\% de K; 6: ATR (-) 50\% de P e K; 7: ATR (-) 100\% de P e 50\% de K; 8: ATR (-) 50\% de P e $100 \%$ de $\mathrm{K}$; 9: ATR () $100 \%$ de $\mathrm{P}$ e K; 10: ATR $(-)$ micronutrientes; 11: sem adubação; 12: sistema não adubado).

${ }^{2}$ Não significativo para análise da variância. 
A análise da variância dos dados não detectou diferenças significativas nas quantidades exportadas de nutrientes pelos grãos de soja.

Tabela 15. Valores médios para micronutrientes exportados por tonelada de grãos de soja, cultivar BRS-133, semeada diretamente sobre a palhada do capim-péde-galinha, submetida a doze níveis de parcelamento da adubação de base da soja, aplicados em época antecipada

\begin{tabular}{|c|c|c|c|c|}
\hline Tratamentos $^{1}$ & $\mathrm{Cu}$ & $\mathrm{Fe}$ & $\mathrm{Mn}$ & $\mathrm{Zn}$ \\
\hline 1 & 29,17 & 74,83 & 17,69 & 40,76 \\
\hline 2 & 46,01 & 73,00 & 22,00 & 41,14 \\
\hline 3 & 27,71 & 65,67 & 19,54 & 41,68 \\
\hline 4 & 18,46 & 72,66 & 18,96 & 42,65 \\
\hline 5 & 19,43 & 88,55 & 17,47 & 43,49 \\
\hline 6 & 24,81 & 87,52 & 16,40 & 42,34 \\
\hline 7 & 16,82 & 68,98 & 17,64 & 43,19 \\
\hline 8 & 18,63 & 87,50 & 18,06 & 45,43 \\
\hline 9 & 37,03 & 77,90 & 18,55 & 43,16 \\
\hline 10 & 37,37 & 82,37 & 18,59 & 44,18 \\
\hline 11 & 71,87 & 64,54 & 18,72 & 42,44 \\
\hline 12 & 31,25 & 73,83 & 17,54 & 43,94 \\
\hline Média & 31,55 & 76,45 & 18,43 & 42,87 \\
\hline $\mathrm{P}>\mathrm{F}$ & n.s. ${ }^{2}$ & n.s. & n.s. & n.s. \\
\hline C.V. (\%) & 80,02 & 13,45 & 15,18 & 8,33 \\
\hline
\end{tabular}

\footnotetext{
1: ATR na soja; 2: ATR (-) 50\% de P; 3: ATR (-) 50\% de K; 4: ATR (-) 100\% de P; 5: ATR (-) 100\% de K; 6: ATR (-) 50\% de P e K; 7: ATR (-) 100\% de P e 50\% de K; 8: ATR (-) 50\% de P e $100 \%$ de K; 9: ATR () 100\% de P e K; 10: ATR () micronutrientes; 11: sem adubação; 12: sistema não adubado).

${ }^{2}$ Não significativo para análise da variância.
}

Comparando-se as médias de exportação de nutrientes por tonelada de grãos, obtidas neste trabalho com os valores apresentados por Tanaka e Mascarenhas (1992) para cinco cultivares de soja, pode-se afirmar que o cultivar BRS-133 exportou maiores quantidades de N, S, Cu e Zn, menores de P, Fe e Mn, e similares de K, Ca e Mg. 


\subsection{Produtividade agrícola da soja}

$\mathrm{Na}$ tabela 16 são apresentados os valores médios observados para a produtividade agrícola de grãos de soja.

Tabela 16. Valores médios observados para produtividade agrícola de soja (PA), cultivar BRS-133, semeada diretamente sobre a palhada do capim-pé-degalinha, submetida a doze níveis de parcelamento da adubação de base da soja, aplicados em época antecipada

\begin{tabular}{|c|c|c|c|}
\hline \multicolumn{3}{|c|}{ Tratamentos } & \multirow{2}{*}{$\begin{array}{c}\text { PA } \\
\left(\mathrm{kg} \mathrm{ha}^{-1}\right)\end{array}$} \\
\hline & Capim-pé-de-galinha & Soja & \\
\hline $\mathrm{T} 1$ & Testmunha $^{1} 1$ & $\mathrm{ATR}^{2}$ & 3.304 \\
\hline $\mathrm{T} 2$ & $50 \%$ de $\mathrm{P}_{2} \mathrm{O}_{5}$ da ATR & ATR (-) $50 \%$ de $\mathrm{P}_{2} \mathrm{O}_{5}$ & 3.629 \\
\hline $\mathrm{T} 3$ & $50 \%$ de $\mathrm{K}_{2} \mathrm{O}$ da ATR & ATR (-) $50 \%$ de $\mathrm{K}_{2} \mathrm{O}$ & 3.696 \\
\hline $\mathrm{T} 4$ & $100 \%$ de $\mathrm{P}_{2} \mathrm{O}_{5}$ da ATR & $\operatorname{ATR}(-) 100 \%$ de $\mathrm{P}_{2} \mathrm{O}_{5}$ & 3.599 \\
\hline $\mathrm{T} 5$ & $100 \%$ de $\mathrm{K}_{2} \mathrm{O}$ da ATR & ATR (-) $100 \%$ de $\mathrm{K}_{2} \mathrm{O}$ & 3.479 \\
\hline T6 & $\begin{array}{l}50 \% \text { de } \mathrm{P}_{2} \mathrm{O}_{5} \text { da ATR } \\
50 \% \text { de } \mathrm{K}_{2} \mathrm{O} \text { da ATR }\end{array}$ & $\begin{array}{l}\text { ATR (-) } 50 \% \text { de } \mathrm{P}_{2} \mathrm{O}_{5} \\
\text { ATR (-) } 50 \% \text { de } \mathrm{K}_{2} \mathrm{O}\end{array}$ & 3.578 \\
\hline $\mathrm{T} 7$ & $\begin{array}{l}100 \% \text { de } \mathrm{P}_{2} \mathrm{O}_{5} \text { da ATR } \\
50 \% \text { de } \mathrm{K}_{2} \mathrm{O} \text { da ATR }\end{array}$ & $\begin{array}{l}\text { ATR (-) } 100 \% \text { de } \mathrm{P}_{2} \mathrm{O}_{5} \\
\text { ATR (-) } 50 \% \text { de } \mathrm{K}_{2} \mathrm{O}\end{array}$ & 3.493 \\
\hline $\mathrm{T} 8$ & $\begin{array}{l}50 \% \text { de } \mathrm{P}_{2} \mathrm{O}_{5} \text { da ATR } \\
100 \% \text { de } \mathrm{K}_{2} \mathrm{O} \text { da ATR }\end{array}$ & $\begin{array}{l}\text { ATR (-) } 50 \% \text { de } \mathrm{P}_{2} \mathrm{O}_{5} \\
\text { ATR (-) } 100 \% \text { de } \mathrm{K}_{2} \mathrm{O}\end{array}$ & 3.527 \\
\hline $\mathrm{T} 9$ & $\begin{array}{l}100 \% \text { de } \mathrm{P}_{2} \mathrm{O}_{5} \text { da ATR } \\
100 \% \text { de } \mathrm{K}_{2} \mathrm{O} \text { da ATR }\end{array}$ & $\begin{array}{l}\text { ATR (-) } 100 \% \text { de } \mathrm{P}_{2} \mathrm{O}_{5} \\
\text { ATR (-) } 100 \% \text { de } \mathrm{K}_{2} \mathrm{O}\end{array}$ & 3.403 \\
\hline T10 & $\begin{array}{l}\text { ATR (-) } 100 \% \text { de } \mathrm{P}_{2} \mathrm{O}_{5} \\
\text { ATR (-) } 100 \% \text { de } \mathrm{K}_{2} \mathrm{O}\end{array}$ & $\begin{array}{l}100 \% \text { de } \mathrm{P}_{2} \mathrm{O}_{5} \text { da ATR } \\
100 \% \text { de } \mathrm{K}_{2} \mathrm{O} \text { da ATR }\end{array}$ & 3.631 \\
\hline T11 & ATR & Testemunha 1 & 3.500 \\
\hline T12 & Testemunha $2^{4}$ & Testemunha 2 & 3.354 \\
\hline Média & & & 3.516 \\
\hline $\mathrm{P}>\mathrm{F}$ & & & n.s. ${ }^{3}$ \\
\hline C.V. $(\%)$ & & & 4,73 \\
\hline
\end{tabular}


Nota-se que a antecipação da adubação de base da soja, por meio de sua aplicação ao solo por ocasião da instalação da cultura de Eleusine coracana (L.) Gaertn., não produziu nenhum efeito na produtividade agrícola de grãos do cultivar BRS-133.

Por outro lado, considerando-se que o solo da área experimental foi cultivado pela primeira vez com a cultura da soja, e que esta foi semeada diretamente sobre a palhada de capim-pé-de-galinha, merece destaque a produtividade agrícola média observada de $3.516 \mathrm{~kg} \mathrm{ha}^{-1}$, com amplitude de 3.304 a $3.696 \mathrm{~kg} \mathrm{ha}^{-1}$.

\subsection{Considerações finais}

O acompanhamento da decomposição da palhada de Eleusine coracana (L.) Gaertn. deixada sobre o solo, ao longo do ciclo da soja poderia dar indícios da quantidade liberada de nutrientes, e se estes estariam sendo disponibilizados para serem absorvidos pela soja. Contudo, esse estudo não foi objeto deste trabalho.

Pode-se assumir que a adubação antecipada da soja para o capim-pé-de-galinha favoreceu-o quanto ao acúmulo de matéria seca e às quantidades acumuladas de fósforo e de cálcio, e que a imobilização desses nutrientes no resíduo vegetal desta cultura não prejudicou o desenvolvimento das plantas de soja. É possível que, a decomposição desta palhada possa ter acontecido em tempo hábil para disponibilizar nutrientes para a cultura da soja.

A ausência de respostas para as variáveis produtividade agrícola e concentração de nutrientes nos grãos de soja, poderia ser atribuída à ocorrência de veranico durante o estádio de enchimento dos grãos $\left(\mathrm{R}_{5}\right)$, o que prejudicaria a translocação de fotoassimilados presentes nas folhas e caules. Contudo, para esta afirmação ser verdadeira, seria necessário ter havido resposta significativa na matéria seca de caules e folhas, indicando maiores valores para os tratamentos mais bem adubados na semeadura da soja.

A hipótese inicial de que a antecipação da adubação não deveria alterar o acúmulo de matéria seca das plantas de soja foi, em parte, comprovada. 


\section{CONCLUSÕES}

- No que concerne à produtividade de matéria seca, o capim Eleusine coracana (L.) Gaertn. constitui-se em espécie recomendável à produção de palhada em sistema de produção sob plantio direto, desde que implantada em solo com média a alta fertilidade.

- A produção de matéria seca e o acúmulo dos nutrientes fósforo e cálcio pelo capim Eleusine coracana (L.) Gaertn. aumentam com a aplicação antecipada da adubação fosfatada de base recomendada para a soja.

- Considerando-se o acúmulo de nutrientes na matéria seca produzida, constata-se que o capim Eleusine coracana (L.) Gaertn. apresenta a seguinte seqüência de absorção: K > $\mathrm{N}>\mathrm{Ca}>\mathrm{Mg}>\mathrm{S}>\mathrm{P}>>\mathrm{Mn}>\mathrm{Fe}>\mathrm{Zn}>\mathrm{Cu}$.

- A antecipação da adubação de base da soja, por ocasião da instalação do capim Eleusine coracana (L.) Gaertn., não diminui o acúmulo de matéria seca e nem interfere com a exportação de nutrientes pelas plantas de soja.

- A utilização do sistema de plantio direto, através da semeadura da soja sobre palhada de Eleusine coracana (L.) Gaertn., em um LATOSSOLO AMARELO Distrófico, cultivado dessa forma pela primeira vez, possibilita a obtenção de média a alta produção de matéria seca na forma de palha e de elevada produtividade de grãos de soja. 
ANEXOS 


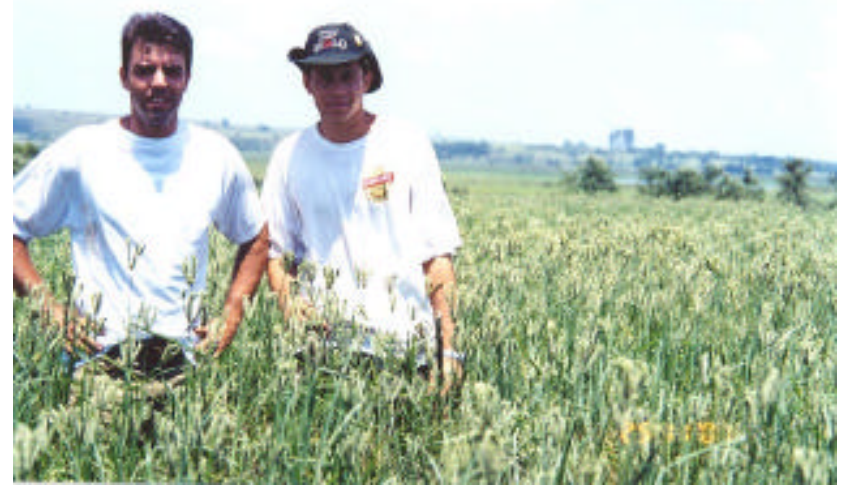

Anexo A - Imagem do capim-pé-de-galinha no estádio de florescimento.

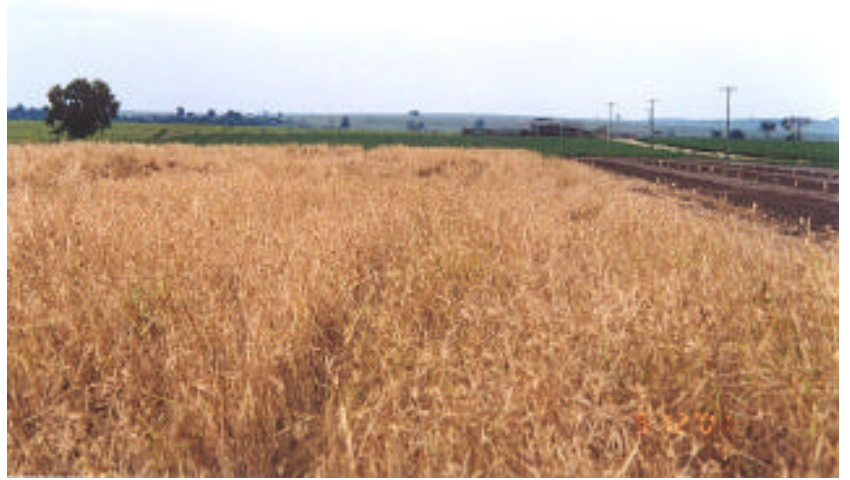

Anexo B - Imagem do capim-pé-de-galinha após o manejo de dessecação.

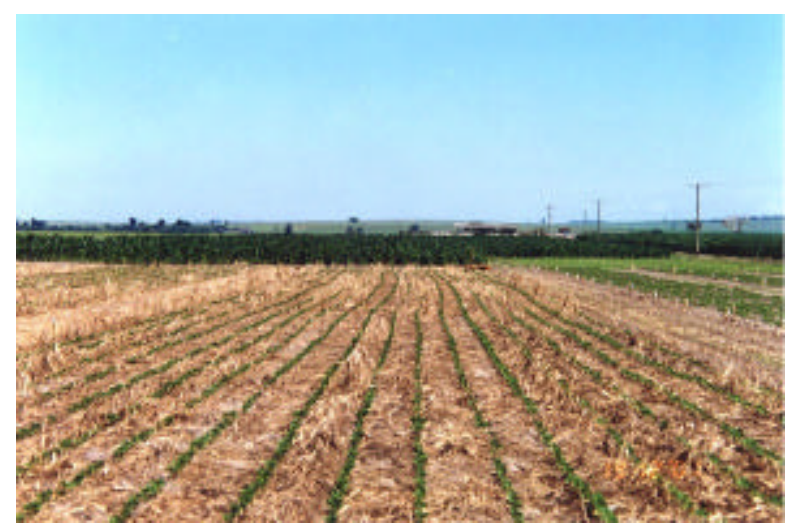

Anexo C - Imagem da área experimental, soja no estádio $\mathrm{V}_{1}$ de desenvolvimento. 


\section{REFERÊNCIAS BIBLIOGRÁFICAS}

AGRAWAL, B.L.; SIAME, J.A.; UPRICHARD, G.T. Status of finger millet Eleusine coracana Gaertn.) in Zambia. In: RILEY, K.W.; GUPTA, S.C.; SEETHARAM,A.; MUSHONGA, J.N. Advances in small millets. New York: International Science Publisher, 1994. cap.2, p.21-28.

ALVARENGA, R.C.; CABEZAS, W.A.L.; CRUZ, J.C.; SANTANA, D.P. Plantas de cobertura de solo para sistema plantio direto. Informe Agropecuario, v.22. n.208, p.25-36, jan./fev. 2001.

BATAGLIA, O.C.; MASCARENHAS, H.A.A. Absorção de nutrientes pela soja. Campinas: IAC, 1977. 36p. (IAC. Boletim Técnico, 41).

BATAGLIA, O.C.; MASCARENHAS, H.A.A.; TEIXEIRA, J.P.F.; TISSELI, O. Acúmulo de matéria seca e nutrientes, em soja cultivar Santa-Rosa. Bragantia, v.35, n.21, p.237-247, jul. 1976.

BAYER, C.; MIELNICZUC, J. Características químicas do solo afetadas por métodos de preparo e sistemas de cultura. Revista Brasileira de Ciência do Solo, v.21, p.105-112, 1997. 
BAYER, C.; MIELNICZUK, J. Dinâmica e função da matéria orgânica. In: SANTOS, G.A.; CAMARGO, F.A.O. Fundamentos da matéria orgânica do solo. Porto Alegre: Gênesis, 1999. cap.2, p.9-39.

BORKERT, C.M.; GAUDÊNCIO, C.A.; PEREIRA, J.E.; OLIVEIRA JUNIOR, A. Nutrientes minerais na biomassa da parte aérea de culturas de cobertura de solo para semeadura direta com rotação de culturas (compact disc). In: CONGRESSO BRASILEIRO DE CIÊNCIA DO SOLO, 27., Brasília, 1999. Anais. Brasília: SBCS; EMBRAPA, CPAC, 1999.

BRASIL. Ministério da Agricultura, Abastecimento e Pecuária. Fertilizantes entregues ao consumidor. http://www.agricultura.gov.br/spa/pagespa/ch01/1_3.xls. (20 out. 2002).

CAIRES, E.F.; FONSECA, A.F. Absorção de nutrientes pela soja cultivada no sistema de plantio direto em função da calagem na superfície. Bragantia, v.59, n.2, p.213$220,2000$.

CÂMARA, G.M.S. Soja: tecnologia da produção. Piracicaba: o autor, 1998. cap.2, p.26-39: Fenologia da soja.

CÂMARA, G.M.S.; HEIFFIG, L.S. Fisiologia, ambiente e rendimento da cultura da soja. In: CÂMARA, GM.S. Soja: tecnologia da produção II. Piracicaba: o autor, 2000. p.81-119.

CANELLAS, L.P.; SANTOS, G.A.; SOBRINHO, N.M.A. Reações da matéria orgânica. In: SANTOS, G.A.; CAMARGO, F.A.O. Fundamentos da matéria orgânica do solo. Porto Alegre: Gênesis, 1999. cap.5, p.69-89. 
CORDEIRO, D.S.; SARRUGE, J.R.; HAAG, H.P.; DE OLIVEIRA, G.D. Produção de matéria seca na soja (Glycine Max (L.) Merrill) em presença de fertilizantes. Anais da Escola Superior de Agricultura 'Luiz de Queiroz”, v.37, p.11-22, 1980.

DAROLT, M.R. Princípios para implantação e manutenção do sistema. In: DAROLT, M.R. Plantio direto: pequena propriedade sustentável. Londrina: IAPAR, 1998. p.16-45 (IAPAR. Circular, 101).

DENARDIN, J.E.; KOCHHANN, R.A. Requisitos para a implantação e a manutenção do sistema plantio direto. In: CNPT; EMBRAPA. FUNDACEP/FECOTRIGO. FUNDAÇÃO ABC. Plantio direto no Brasil. Passo Fundo: Aldeia Norte, 1993. p.19-27.

ESTEVES, J.A.F. Produção de soja em função da antecipação da adubação fosfatada e potássica em semeadura direta. Botucatu, 2000. 107p. Dissertação (Mestrado) Faculdade de Ciências Agronômicas, Universidade Estadual Paulista "Júlio de Mesquita Filho".

FAGERIA, N.K.; BALIGAR, V.C.; JONES, C.A. Growth and mineral nutrition of field crops. 2.ed. New York: Marcel Dekker, 1997. 624p.

FAO. El sorgo y el mijo en la nutrición humana. Roma, 1995. 197p.

FEDERAÇÃO BRASILEIRA DE PLANTIO DIRETO NA PALHA. Evolução do plantio direto no Brasil - 72/01. http://www.febrapdp.org.br/area_PD_Brasil_2002.htm. (20 out. 2002).

FEHR, W.R.; CAVINESS, C.E. Stages of soybean development. Ames, Yowa. Yowa State University, Cooperative Extension Service. 11p. 1977. (Special Report, 80). 
FNP CONSULTORIA. Soja: safra brasileira 2001/2002. http://www.fnp.com.br/foldia2/culturas/soja/estatisticas/sojaproducao.html. (20 out. 2002).

FOLONI, J.S.S.; ROSOLEM, C.A.; ERLO, J.V.; TAVARES, C.A. Antecipação da adubação potássica da soja em rotação com milheto (compact disc). In: REUNIÃO BRASILEIRA DE FERTILIDADE DO SOLO E NUTRIÇÃO DE PLANTAS, 25.; REUNIÃO BRASILEIRA SOBRE MICORRIZAS, 9; SIMPÓSIO BRASILEIRO DE MICROBIOLOGIA DO SOLO, 7.; REUNIÃO BRASILEIRA DE BIOLOGIA DO SOLO, 4., Rio de Janeiro, 2002. Resumos. Rio de Janeiro: SBCS; UFRRJ, 2002.

FREIRE, F.M.; SARRUGE, J.R. Produção de matéria seca, nodulação e absorção de nutrientes pela soja (Glycine Max (L.) Merrill) em função de níveis de fósforo e zinco, em solos de Minas Gerais. Anais da Escola Superior de Agricultura 'Luiz de Queiroz", v.36, p.509-537, 1979.

GOUDRIAAN, J.; LAAR, H.H. van. Modelling potential crop growth processes. Dordrecht: Kluwer Academic, 1994. v.2. 238p.

HANWAY, J.J.; WEBER, C.R. Dry matter accumulation in eight soybean soybean (Glycine max (L.) Merrill) varieties. Agronomy Journal, v.63, p.227-230, 1971a.

HANWAY, J.J.; WEBER, C.R. N, P and K percentages in soybean (Glycine max (L.) Merrill) plant parts. Agronomy Journal, v.63, p.286-290, 1971 b.

KANTHACK, R.A.D. Efeito de doses e modos de aplicação de potássio em características agronômicas da soja. Piracicaba, 1995. 118p. Dissertação (Mestrado) - Escola Superior de Agricultura "Luiz de Queiroz", Universidade de São Paulo. 
MARQUES, R.R.; DELAVALE, F.G.; LAZARINI, E.; BUZETTI, S.; ARATANI, R.G. Quantidade de nutrientes restituídos ao solo através de plantas de cobertura e resíduos das culturas de soja e milho, em função de presença ou ausência de calcário na implantação do sistema plantio direto (compact disc). In: REUNIÃO BRASILEIRA DE FERTILIDADE DO SOLO E NUTRIÇÃO DE PLANTAS, 25.; REUNIÃO BRASILEIRA SOBRE MICORRIZAS, 9.; SIMPÓSIO BRASILEIRO DE MICROBIOLOGIA DO SOLO, 7.; REUNIÃO BRASILEIRA DE BIOLOGIA DO SOLO, 4., Rio de Janeiro, 2002. Resumos. Rio de Janeiro: SBCS; UFRRJ, 2002.

MASCARENHAS, H.A.A. Acúmulo de matéria seca, absorção e distribuição de elementos na soja, durante o seu ciclo vegetativo. Piracicaba, 1972. 100p. Tese (Doutorado) - Escola Superior de Agricultura "Luiz de Queiroz" - Universidade de São Paulo.

MASCARENHAS, H.A.A. Acúmulo de matéria seca, absorção e distribuição de elementos, durante o ciclo vegetativo da soja. Campinas: IAC, 1973. 48p. (IAC. Boletim Técnico, 6).

MASCARENHAS, H.A.A.; NEPTUNE, A.M.L.; MURAOKA, T.; BULISANI, E.A.; HIROCE, R. Absorção de nutrientes por cultivares de soja (Glycine Max (L.) Merrill). Revista Brasileira da Ciência do Solo, v.4, p.92-96, 1980.

MATHAN, K.K. Direct effect of magnesium, potassium and calcium on yield, protein content and $\mathrm{Mg}$ uptake by fingermillet (Eleusine coracana) in acid soil. Indian Journal of Agronomy, v.40, n.4, p.609-612, Dec. 1995. 
MENDONÇA, E.S.; OLIVEIRA, F.H.T. Fornecimento de nutrientes pela matéria orgânica do solo. In: SIMPÓSIO SOBRE FERTILIDADE DO SOLO E NUTRIÇÃO DE PLANTAS NO SISTEMA PLANTIO DIRETO, 1., Ponta Grossa, 2000. Anais. Ponta Grossa: Associação de Engenheiros Agrônomos dos Campos Gerais, 2000. p.70-81.

MONTEIRO, F.A.; RAMOS, A.K.B.; DE CARVALHO, D.D.; DE ABREU, J.B.R.; DAIUB, J.A.S.; DA SILVA, J.E.P.; NATALE, W. Cultivo de Brachiaria brizantha Stapf. Cv. Marandu em solução nutritiva com omissões de macronutrientes. Scientia Agricola, v.52, n.1, p.135-141, 1995.

MORAES, R.N.S. Decomposição das palhadas de sorgo e milheto, mineralização de nutrientes e seus efeitos no solo e na cultura do milho em plantio direto. Lavras, 2001. 90p. Dissertação (Mestrado) - Universidade Federal de Lavras.

MULATU, T.; KEBEDE, Y. Finger millet importance and improvement in Ethiopia. In: RILEY, K.W.; GUPTA, S.C.; SEETHARAM, A.; MUSHONGA, J.N. Advances in small millets. New York: International Science, 1994. cap.5, p.5159.

MUSHONGA, J.N.; MUZA, F.R.; DHLIWAYO, H.H. Development, current and future research strategies on finger millet in Zimbabwe. In: RILEY, K. W.; GUPTA, S. C.; SEETHARAM, A.; MUSHONGA, J. N. Advances in small millets. New York: International Science, 1994. cap.1, p.11-19.

MUZILLI, O. Princípios e perspectives de expansão. In: INSTITUTO AGRONÔMICO DO PARANÁ. Plantio direto no estado do Paraná. Londrina, 1981. (IAPAR. Circular, 23).

MUZILLI, O. Influência do sistema de plantio direto, comparado ao convencional, sobre a fertilidade da camada arável do solo. Revista Brasileira da Ciência do Solo, v.7, p.95-102, 1983. 
MUZILLI, O. A fertilidade do solo no sistema plantio direto: bases para o manejo sustentável. In: SIMPÓSIO SOBRE FERTILIDADE DO SOLO E NUTRIÇÃO DE PlANTAS NO SISTEMA PlanTIO DIRETO, 1., Ponta Grossa, 2000. Anais. Ponta Grossa: Associação de Engenheiros Agrônomos dos Campos Gerais, 2000. p.1-16.

NOLETO, L.G.; GOEDERT, W.J. Avaliação de perdas de solo e água por erosão, em sistemas de cultivo convencional e plantio direto (compact disc). In: CONGRESSO BRASILEIRO DE CIÊNCIA DO SOLO, 27., Brasília, 1999. Anais. Brasília: SBCS; EMBRAPA, CPAC, 1999.

ODUORI, C.O. Small millets production and research in Kenya. In: RILEY, K.W.; GUPTA, S.C.; SEETHARAM, A.; MUSHONGA, J.N. Advances in small millets. New York: International Science, 1994. cap.7, p.67-73.

PEIXOTO, C.P. Análise de crescimento e rendimento de três cultivares de soja em três épocas de semeadura e três densidades de plantas. Piracicaba, 1998. 151p. Tese (Doutorado) - Escola Superior de Agricultura "Luiz de Queiroz", Universidade de São Paulo.

PILANE, M.S.; SALVE, R.B.; PAWAR, V.S.; BHOI, P.G. Response of fingermillet (Eleusine coracana) varieties to nitrogen and phosphorus. Indian Journal of Agronomy, v.42, n.4, p.637-640, Dec. 1997.

RAIJ, B.van; CANTARELlA, H.; QUAGGIO, J.A.; FURLANI, A.M.C. (Ed.). Recomendações de adubação e calagem para o estado de São Paulo. 2.ed. Campinas: IAC, FUNDAG, 1997. 285p. (IAC. Boletim Técnico, 100).

RAO, K.L.; RAO, C.P.; RAO, K.V. Response of finger millet (Eleusine coracana L. Gaertin) cultivars to nitrogen under rainfed conditions. Indian Journal of Agronomy, v.34, n.3, p.302-306, Sept. 1989. 
RAO, K.L.; RAJU, D.V.N.; RAO, C.P. Response of ragi (Eleusine coracana (L.) Gaertn.) to varying spacings under irrigated conditions. Indian Journal of Agronomy, v.35, n.3, p.275-279, 1990.

RAO, K.L.; RAJU, D.V.N.; CHITKALA DEVI, T.; RAO, C.P.; RAO, T.K.V.V.M. Effect of level and time of nitrogen application to fingermillet (Eleusine coracana) under rainfed condition. Indian Journal of Agronomy, v.36, p.91-96, 1991. Supplement.

REDDY, M.G.R.K.; REDDY， S.R.; REDDY， P.R.; SUBRAHMANYAM， K.; SUBRAHMANYAM, M.V.R. Effect of nitrogen on nitrogen and phosphorus uptake of fingermillet. Indian Journal of Agronomy, v.31, n.1, p.29-32, 1986.

ROSOLEM, C.A.; MARCELLO, C.S. Crescimento radicular e nutrição mineral da soja em função da calagem e adubação fosfatada. Scientia Agricola, v.55, n.3, p.448455, set./dez. 1998.

ROSSI, C.; MONTEIRO; F.A. Parâmetros produtivos, nutrição em fósforo e atividade foliar da fosfatase ácida no capim-braquiária cultivado em solução nutritiva. Boletim da Indústria Animal, v.56, n.2, p.127-135, 1999.

SAINI, J.P.; NEGI, S.C.; SINGH, C.M. Response of fingermillet (Eleusine coracana) genotypes to nitrogen application under cold desert conditions. Indian Journal of Agronomy, v.41, n.1, p.61-64, Mar. 1996.

SANTOS, H.P.; FONTANELI, R.S.; TOMM, G.O. Efeito de sistemas de produção de grãos e de pastagens sob plantio direto sobre o nível de fertilidade do solo após cinco anos. Revista Brasileira da Ciência do Solo, v.25, p.645-653, 2001.

SINGH, R.V.; ARYA, M.P.S. Effect of different production components on yield of finger millet (Eleusine coracana). Indian Journal of Agronomy, v.42, n.3, p.484487, Sept. 1997. 
SUBBA RAO, A.; PRABHU, U.H. Effect of fertilizer and variety on nutritional quality of finger millet (Eleusine coracana) straw. Indian Journal of Agricultural Sciences, v.66, n.4, p. 240-242, Apr. 1996.

TANAKA, R.T.; MASCARENHAS, H.A.A. Soja: nutrição, correção do solo e adubação. Campinas: Fundação Cargill, 1992. 60p. (Série Técnica, 7).

VEIGA, C.M. Modelo empírico para a seleção de máquinas agrícolas na cultura da soja considerando a pontualidade na semeadura. Piracicaba, 2000. 75p. Dissertação (Mestrado) - Escola Superior de Agricultura "Luiz de Queiroz", Universidade de São Paulo.

VERNETTI, F.J. Soja: genética e melhoramento. Campinas: Fundação Cargill, 1983. $2 \mathrm{v}$.

WERNER, J.C. Adubação de pastagens. Nova Odessa: Instituto de Zootecnia, 1986. 49p. (IZ. Boletim Técnico, 18).

WISNIEWSKI, C.; HOLTZ, G.P. Decomposição da palhada e liberação de nitrogênio e fósforo numa rotação aveia-soja sob plantio direto. Pesquisa Agropecuária Brasileira, v.32, n.11, p.1191-1197, nov. 1997. 
APÊNDICES 
Apêndice 1 - Valores dos quadrados médios para as variáveis analisadas (PAS: produtividade agrícola; concentração dos nutrientes nos grãos de soja)

\begin{tabular}{|c|c|c|c|c|c|c|c|c|c|c|c|c|}
\hline \multirow{2}{*}{$\begin{array}{l}\text { Fonte de } \\
\text { variação }\end{array}$} & \multirow[b]{2}{*}{ GL } & \multicolumn{11}{|c|}{ Variáveis } \\
\hline & & PAS & $\mathrm{N}$ & $\mathrm{P}$ & $\mathrm{K}$ & $\mathrm{Ca}$ & $\mathrm{Mg}$ & $S$ & $\mathrm{Cu}$ & $\mathrm{Fe}$ & $\mathrm{Mn}$ & $\mathrm{Zn}$ \\
\hline Bloco & 2 & 80188,663 & 43,206 & 0,01604 & 0,19507 & 0,18673 & 0,09080 & 0,03054 & 1653,083 & 74,045 & 28,381 & 7,2933 \\
\hline Tratamento & 11 & 42503,061 & 19,290 & 0,24969 & 0,78030 & 0,03703 & 0,02309 & 0,05370 & 697,859 & 211,725 & 5,651 & 5,3733 \\
\hline Resíduo & 22 & 27672,686 & 25,850 & 0,19172 & 1,18818 & 0,02969 & 0,02262 & 0,03405 & 604,324 & 99,026 & 6,113 & 8,1284 \\
\hline
\end{tabular}

Apêndice 2 - Valores dos quadrados médios para a variável "matéria seca total de plantas de soja" analisada e relativos aos estádios fenológicos coletados

\begin{tabular}{|c|c|c|c|c|c|c|c|c|}
\hline \multirow{2}{*}{$\begin{array}{l}\text { Fonte de } \\
\text { variação }\end{array}$} & \multirow[b]{2}{*}{ GL } & \multicolumn{7}{|c|}{ Estádios fenológicos } \\
\hline & & $\mathrm{V}_{4}$ & $\mathrm{~V}_{7}$ & $\mathrm{~V}_{10} / \mathrm{R}_{2}$ & $\mathrm{R}_{3}$ & $\mathrm{R}_{5,3}$ & $\mathrm{R}_{6}$ & $\mathrm{R}_{7,2}$ \\
\hline Blocos & 2 & 0,0001988 & 0,0029703 & 0,0000696 & 0,020760 & 0,187574 & 0,388044 & 0,193372 \\
\hline Tratamento & 11 & 0,0000251 & 0,0008189 & 0,0023165 & 0,007129 & 0,028196 & 0,022594 & 0,045118 \\
\hline Resíduo & 22 & 0,0000355 & 0,0005623 & 0,0032624 & 0,010704 & 0,031305 & 0,044271 & 0,033165 \\
\hline
\end{tabular}


Apêndice 3 - Valores dos quadrados médios para as variáveis analisadas (PMS: produção de matéria seca do capim-pé-degalinha; concentração dos nutrientes na parte aérea da planta)

\begin{tabular}{|c|c|c|c|c|c|c|c|c|c|c|c|c|c|}
\hline \multirow{2}{*}{$\begin{array}{l}\text { Fonte de } \\
\text { variação }\end{array}$} & \multirow[b]{2}{*}{ GL } & \multicolumn{12}{|c|}{ Variáveis } \\
\hline & & PMS & $\mathrm{N}$ & $\mathrm{P}$ & $\mathrm{K}$ & $\mathrm{Ca}$ & & $\mathrm{Mg}$ & $\mathrm{S}$ & $\mathrm{Cu}$ & $\mathrm{Fe}$ & $\mathrm{Mn}$ & $\mathrm{Zn}$ \\
\hline Bloco & 2 & 892485,3 & 36,1 & 0,260 & 1,36 & 1,05 & & 0,13 & 1,25 & 5,3 & 946,5 & 20559,6 & 24,0 \\
\hline Tratamento & 11 & 2846139,0 & 6,0 & $0,299 * *$ & 14,04 & 0,90 & $* *$ & 0,60 & 0,16 & 24,8 & 64,8 & 2327,2 & $265,8 * *$ \\
\hline Resíduo & 22 & 846527,4 & 7,2 & 0,055 & 7,96 & 0,26 & & 0,27 & 0,20 & 52,3 & 100,7 & 929,9 & 54,6 \\
\hline
\end{tabular}

